\title{
EROTIC MIRRORS. EROTICISM IN THE MIRROR. AN ICONOGRAPHY OF LOVE IN ANCIENT GREECE (FIFTH TO FOURTH CENTURY B.C.)*
}

\author{
Fábio Vergara Cerqueira ${ }^{1}$
}

\begin{abstract}
This text consists of an interpretive essay about the meaning(s) of the "mirror" as an object in Mainland and Aegean Greece (in contrast to Western/Colonial Greece), based on iconography. I take into consideration two distinct repertoires of images: the paintings of Attic vases (late sixth - early fourth century B.C.) and the figurative decoration on the mirrors themselves, in relief or engraved (late fifth - early third century B.C.). The central focus of the analysis is the iconography registered on mirrors produced in the four main manufacturing centers of Greece (Athens, Corinth, Chalcis, Ionia). Greeks produced three types of mirrors between Late Archaic and Early Hellenistic times: hand-mirrors with handle, table mirrors with stand, and round box mirrors, the latter being the most important to this study. Box mirrors may bear iconography on their folding cover, in relief on the external surface (repoussé) or engraved on the interior surface. In contrast to the iconography of the vases of Magna Graecia, in which the mystic component stands out from the other symbolic aspects, in the case of the iconography of Greek mirrors erotic symbolism and the relation with the goddess Aphrodite predominate. This goddess protects all categories of women (hetaerae and "citizen-women", married or brides) and all modalities of eroticism. Under the auspices of love and desire, the symbolic power of the mirror can be related to an inclusive eroticism, which unites, that which society separates.
\end{abstract}

\section{Key words}

Mirror; material culture; iconography; pottery; eroticism; Aphrodite.

\footnotetext{
* Translation: José A. Curbelo; Priscilla Ferreira Ulguim (revision).

1 Full Professor, Federal University of Pelotas, Pelotas, Brazil. E-mail: fabiovergara@uol.com.br
} 


\section{Resumo}

O presente texto consiste em um ensaio interpretativo sobre o(s) sentido(s) do objeto espelho na Grécia egeia (em contraste à Grécia ocidental/colonial), com base na iconografia, levando em consideração dois repertórios imagéticos distintos: a pintura dos vasos áticos (final do sexto a início do quarto século) e a decoração figurada dos espelhos em si, em relevo e gravada por incisão (final do quinto a início do terceiro século). $O$ foco central de análise é a iconografia registrada nos espelhos produzidos nos quatro principais centros da indústria grega de espelhos (Atenas, Corinto, Cálcis, Jônia). Dentre os três tipos de espelho produzidos, quais sejam, espelho de mão, espelho de mesa e espelho de caixa, é fundamentalmente o terceiro tipo que contribui para este estudo. Os espelhos de caixa podem portar iconografia em sua cobertura dobrável, em relevo na superfície externa e gravada por incisão na superfície interna. Em contraste com a iconografia de vasos da Magna Grécia, em que o componente místico se sobressai entre vários simbolismos, no caso da iconografia do/no espelho produzida na Grécia egeia prevalece o simbolismo erótico e a ligação com Afrodite, por meio de cuja proteção se acolhem todas as categorias de mulheres (hetairas, "mulheres-cidadãs" casadas ou noivas) e todos as modalidades de amores - o poder simbólico do espelho estaria relacionado a um erótica inclusiva, que une sob a égide do amor e desejo aquilo que a sociedade separa.

\section{Palavras-chave}

Espelho; cultura material; iconografia; cerâmica; erótica; Afrodite. 


\section{Mirror images and images in the mirror: meanings of an object}

The mirror is one of the most prominent products of Greek metalwork. They were bearers of ornamental refinement from the late sixth century B.C. as exemplified by the standing mirrors with caryatid-shaped handles or stands (Fig. 1). Mirrors are objects that are present in both the material registry (mainly funerary) as well as in the iconographic registry, especially in vase painting. Beyond pragmatic uses, the possible meanings associated with this object pique our interest, because "since ancient times, the mirror has fascinated the human spirit" (Kuzmina 2013: 156).

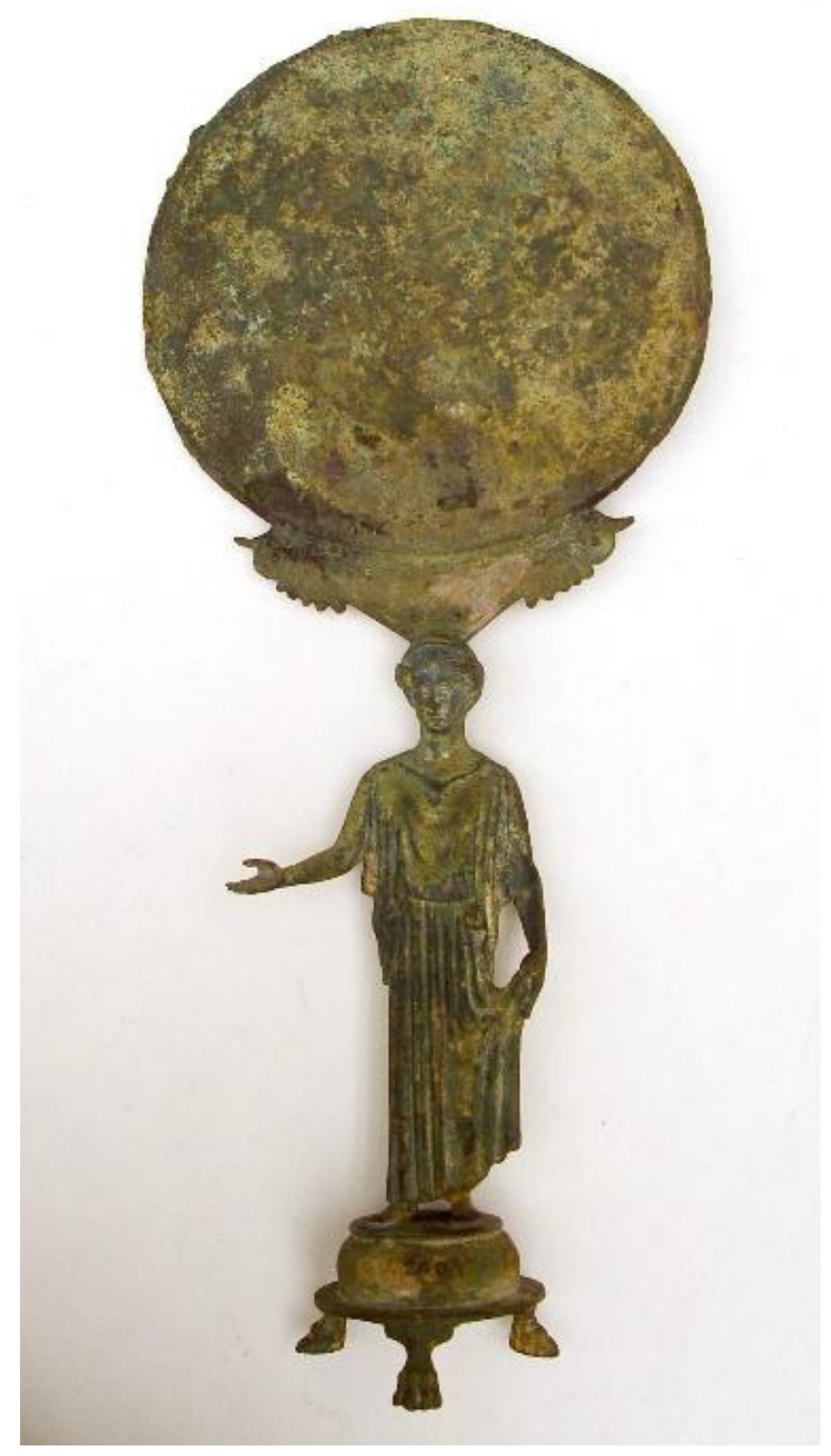

Fig. 1. Table mirror with caryatid stand: Originally the female figure had a dove in her right hand. London, British Museum, inv. 1873,0820.235. Production: Argos. Origin: Athens. c. 460 B.C. (CTrustees of the British Museum 
Between the Late Archaic and Early Hellenistic periods, four centers in Aegean and mainland Greece stood out in terms of the production of mirrors: Chalcis, Athens, Corinth and Ionia. The mirror industry expanded to the Italian peninsula, where significant production had developed, especially in Etruria and Magna Graecia, where Tarentum and Epizephyrian Locris were leading production centers in southern Italy (Treister, 1996: 206-209). A special feature of these mirrors was the esthetic elegance and communicative refinement of supporting figured images. These images were either constitutive parts of their handles and stands, or scenes represented on one of the surfaces (in relief or engraving).

Contemporaneously with this metalcraft industrial production, the object "mirror" was the focus of visual productions, as a visual referent, widely represented in Attic vase painting.

Our interest in this study is to reflect on meanings attributed to the "mirror" as an object, and to its representations in ancient Greek culture. We attempt to observe to what degree the representations of the / in the "mirror world"2, present similarities or discontinuities in mainland and Aegean Greece, in comparison with those observed in the Greek West. Namely in Magna Graecia, colonial contexts engendered richly intercultural situations of hybridization, which stimulated reformulations or discontinuities of cultural meanings brought together with social practices or objects introduced in southern Italy and Sicily by colonial contacts.

Studies of the mirror in Greek culture have approached it in a generic way, without considering cultural discontinuities and singularities existing between mainland and Aegean Greek contexts and colonial, intercultural Greek contexts (Frontisi-Ducroux, Vernant, 1997. Hartlaub 1951. Delatte, 1932). We focus in this essay on mainland and Aegean Greece as a space that produced its own social image of the mirror; we have previously approached the context of Western Greece (Vergara Cerqueira, 2018, in press).

According to Eugenia Kuzmina (2013: 157), "the human conscience granted mirrors aesthetic, axiological and gnoseological values, which, in turn, determined the polyfunctional and polysemantic roles of the object in culture". She means the aesthetic meaning would be related to the "technical qualities" of the object; the axiological function, to the "aptness

\footnotetext{
2 "Monde du miroir", expression of Françoise Frontisi-Ducroux to describe the world created around the mirror (Frontisi-Ducroux, Vernant 1997: 51-133).
} 
of the object to act as indicator of value judgments"; and the gnosiological aspect, to the possibility to "serve as a means of learning and selfknowledge". Before such interpretative possibilities, we propose here to reflect about the potentiality - and necessity - of interpreting the meanings of the mirror based on the iconographical evidence, namely two kinds of evidence in this case: images represented on the surfaces of the mirror itself and images of mirrors as part of scenes painted on vase surfaces. We think that this visual repertoire contains interconnected features concerning the aesthetic and axiological values mentioned above, such that the images of mirrors, and the images on the mirror express and, more than that, configure - a symbolism that defines the social and cultural status of the mirror. However, in order to understand the particular meaning of the mirror in mainland and Aegean Greece, one must take into account that which belongs to the material culture under analysis (the material media of such scenes, it means, the object "mirror" itself, and the thing represented: the visual referent "mirror"):

\begin{abstract}
The mirror in its material dimension is part of the historical process, and its fate cannot be separated from its cultural context. It is also characterized by dynamism, insofar as its conceptual orientation and perspective is enriched in each age, achieving new semantic implications. In each epoch, the human being defined his conception of the object, attributed to it certain values and functions; each epoch has set up a particular image of the mirror (Kuzmina, 2013: 158).
\end{abstract}

Thus, we seek an understanding of the status of the mirror, through which a social image of it is configured, based on an Archaeology of the Image, which takes into account "varied types of objects that served as media for such images or object that were themselves images" (Sarian, 1999: 70). This is how we anchor our reflection on the dialogue between images painted on vases and images recorded on mirrors.

It should be remembered that the "mirror" as an object (the referent) is one thing, with its primary practical proposals linked to the toilette and feminine personal vanity (Vernant, 1989: 118; Kuzmina, 2013: 158), and another thing is the graphical representation of the mirror, namely the "mirror" as a visual sign. This sign, following Saussure's definition, is composed by the significant ("signifier", the drawing and painting that portrays it in the vase painting) - and by the connected signifiés ("signifieds", meanings), respecting pragmatic or symbolic uses of such objects. It is also worth mentioning that the pragmatic dimension of an object like the mirror is not necessarily limited to its primary function of reflection during private toilette, a supposedly female function (Vernant 
1989: 118)3. The object may embody other uses, such as religious ones e.g. worship of Eros (Schneider-Herrmann 1970) - uses that aside from adding gender aspects (such as female bonding), may add mystic elements (Hartlaub, 1951. Delatte, 1932) to the mirror's symbolic dimension, so as to merge erotic aspects with funerary or oracular ones (in such uses female exclusivity gives way, as it can be used also by men) (Cassimatis, 1998: 297-301).

The iconography of Apulian vases of the fourth century B.C. is a testimony to the fact that, in Magna Graecia, the symbolism of the visual representation of the mirror incorporates other relevant meanings beyond personal aesthetic care: mystical, religious, funerary and oracular meanings in particular (Vergara Cerqueira, 2018) - aspects that are barely present in the iconography of the mirror in Attic vases. The confirmation of this contrast on the representation of the mirror, verified in the comparison between Attic and Apulian vase painting, provokes us to understand the particularity of the predominant symbolism in the cultural appropriation of the "mirror" as an object in mainland and Aegean Greece, where several important mirror-producing industries were concentrated.

In this sense, Lilian Balensiefen (1990:28) sustains that, in Ancient Greece, the mirror "as a cosmetic apparatus, is predominantly associated with the feminine sphere and functions as a symbol of female beauty and youth", blending practical and symbolic dimensions. According to this author, the iconographic context of mirrors in the art of mainland Greece is characterized most frequently by scenes of daily life, referring to the gunaikaion (feminine domestic space) and toilette, representations that could also be inserted in a burial context. I think, in the case of the iconography of Attic vases or of Corinthian mirrors, the realm of the ergasterion or porneion (brothel), also a feminine frame yet with other social implications, should be accentuated. Balensiefen upholds that the mirror is generically treated as a utensil to which a function of attribute is added (as a rule, a gender attribute, pertaining to women in general, but could also be the attribute of a female divinity, particularly Aphrodite).

Utilitarian and symbolic aspects intertwine in various forms within the set of elements that comprise the "mirror". The handles, for example, can be very simple, however they may become an element of ornamentation that may contain, or not, iconographic content. The iconographic content in the ornamentation of the mirror handle, commonly associated with

33 “(...) ses propriétés naturelles. Dans son rôle normal - refléter les apparences, offrir l'image des objets visibles placés devant lui (...)." 
Aphrodite or Eros, may bear symbolic content, for example related to eroticism. A unique characteristic of Greek bronze mirrors and those produced under influence of the Greek tradition in Magna Graecia and Etruria, is that they bear rich iconography on their external or internal surfaces via relief or incision, respectively. The presence of the decoration is testimony not only to the development of sophisticated manufactured items with high-specialized craftspeople, but above all to the material and symbolic importance of this object in Greek culture. This reinforces the importance of seeking to decipher their symbolic content, very much intelligible to the users of the time, users of mirrors as objects and as visual signs, yet difficult to comprehend for the modern interpreter, demanding hermeneutic effort. We take the liberty to appropriate the statement of Hélène Cassimatis (1992: 111; 1998: 298), in referring to the iconography of Apulian vases: "the most enigmatic object is the mirror", its "meaning remaining evasive".

In this essay on the Greek mirror, we will seek to reflect on its cultural symbolism by comparatively analyzing the iconography of the mirror (represented on Attic vases) and the iconography on the mirror, between the end of the sixth century B.C. and the end of the fourth century B.C. In this fashion, firstly I will briefly present the mirror in the Ancient World. I will then comment on the iconography of the mirror in Greece, addressing mainly Attic vase painting, and afterwards, on the figurative decoration on mirrors themselves, namely from the four principal Greek wares of mirrors production (Chalcis, Athens, Corinth and Ionia).

\section{Regarding the mirror as object in the Ancient World}

The manufacture of mirrors from sheets of polished metal, initially copper, later bronze, began in Mesopotamia in the fourth millennium before Christ, arriving later in Egypt. This manufacture substituted the previous solutions employed by humans for reflection, such as the surface of still water, preferably within a receptacle, or polished stone such as obsidian, which was used in this manner from the sixth millennium B.C. in Anatolia. For many centuries bronze mirrors predominated in the Mediterranean, reflecting one's image upon a polished surface, slightly concave or convex. The earliest archaeological remains of the use of glass as surface for the reflection of images in Greece date from the third century A.D. According to Pliny the Elder 
(N.H. XXXVI.66) ${ }^{4}$, the oldest literary witness to the manufacture of glass mirrors, their development began in Sidon, probably due to local improvements in glass-blowing technology, and would have occurred in the first century A.D. (Melchior-Bonnet, 2002: 12. Glyn-Jones, 1996: 136), becoming more widely disseminated during the Nerva-Antonine period.
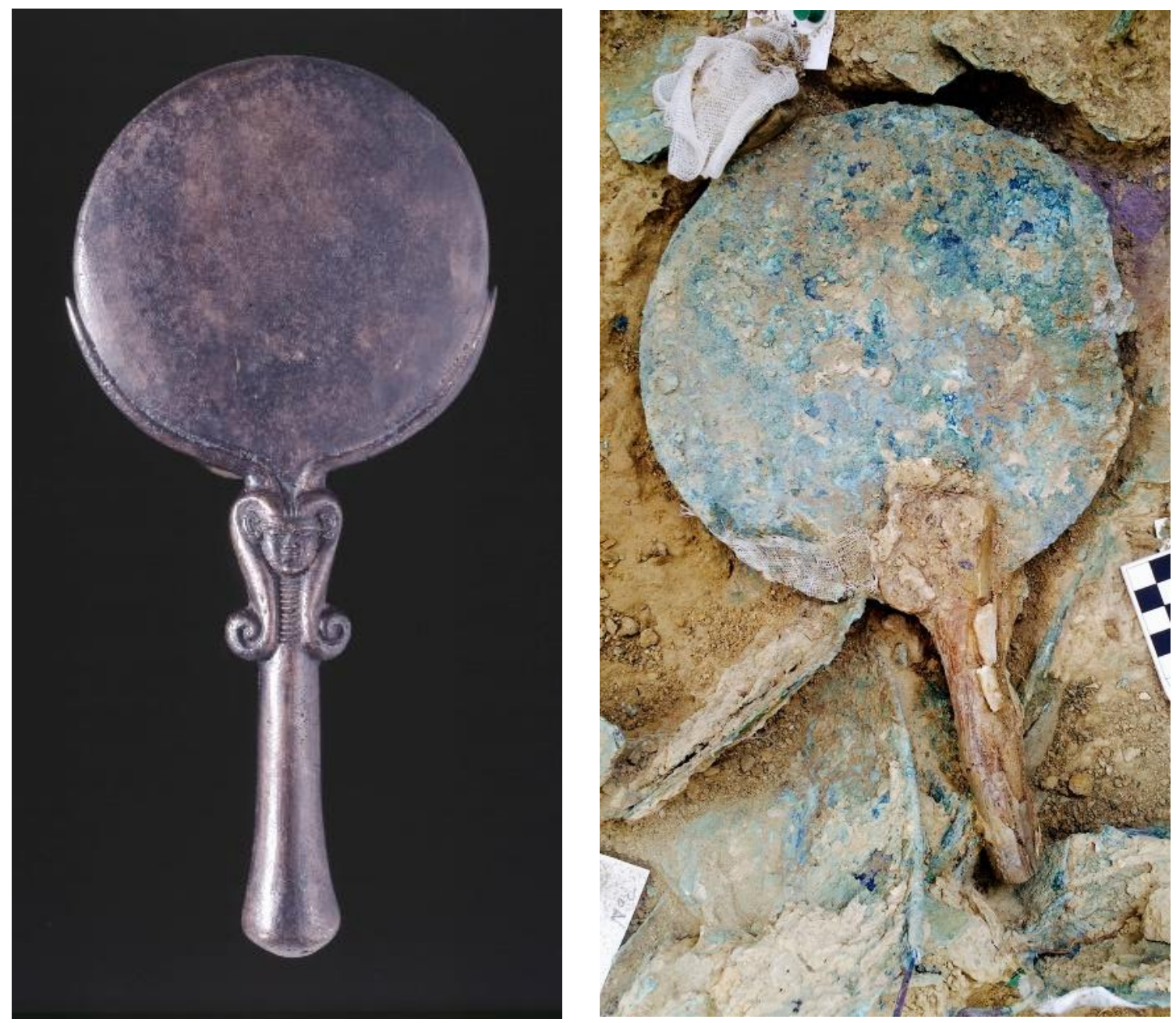

Fig. 2. (left) Egyption hand mirror: Bronze. London, British Museum, EA29428 (1897.0511.144). New Kingdom. (T) Trustees of the British Museum

Fig. 3. (right) Hand mirror, bronze (disc) and ivory (handle): Tomb of the "Griffin Warrior", Pylos. CPhoto: Department of Classics/University of Cincinnati

4 "This mass is again subjected to fusion in the furnace, for the purpose of colouring it; after which, the glass is either blown into various forms, turned in a lathe, or engraved like silver. Sidon was formerly famous for its glass-houses, for it was this place that first invented mirrors" (Bostock). (...) ex massis rursus funditur in officinis tinguiturque, et aliud flatu figuratur, aliud torno teritur, aliud argenti modo caelatur, sidone quondam his officinis nobili, siquidem etiam specula excogitaverat (Mayhoff). 
Egypt stands out for the great number of preserved mirrors there. These are composed of two parts: a rounded sheet of bronze with a polished surface, and the attached handle, which could be made of a different material, most commonly of wood. The bronze sheet, normally rounded, had an alteration at the base to permit the attachment of the handle. The handles could possess a base with an adapted format as to be able to independently stand upright, as observed in a piece preserved at the Louvre $^{5}$. More sophisticated models could be made from one piece entirely formed in bronze. In such cases, the handle could have aesthetic elaboration, such as the mirror preserved in the British Museum, with the upper part of its handle in the form of the head of Hathor (Fig. 2)6, which, beyond reinforcing its luxurious nature, adds symbolic value, associating the mirror with the realm of love, festivity, glamor, and dignity of the god-wife.

Mirrors from Aegean cultures, dating back to the second millennium B.C., were found in the eastern Mediterranean basin. A team from the University of Cincinnati discovered recently a bronze mirror, with an ivory handle, in the tomb of a warrior at Pylos in the Peloponnese dating approximately from 1500 B.C., indicating that the possession of an object of this nature in Mycenaean society was a sign of elite status ${ }^{7}$ (Fig. 3).

The hand mirrors of the Argo-Corinthian variety date back to the Archaic period, and are the oldest Greek mirrors, followed by standing mirrors that appeared in the Classic period. In the late Archaic and Classic periods, the Greeks produced three kinds of mirrors: hand mirrors with handles, table mirrors with stands, and round box mirrors with lids. The latter consisted of two articulated metal discs, one polished on the front, and the cover hinged to it (Ridder, 1909: 1424; Mattusch, 2010: 402) (Fig. $16 a-b)^{8}$. In the fifth and fourth centuries B.C., according to the archaeological record, first the table and then the box mirror predominated, whereas the evidence of Attic vase painting reveals the

\footnotetext{
${ }^{5}$ Egyption hand-mirror. Bronze plate, wooden handle. Paris, Louvre, 162. c. 1.300 B.C.

6 Despite the head of Hathor being among the most common, it was customary to decorate the upper portion of the handle with other divinities: falcon head, thus of the god Horus, British Museum, EA32583 and EA2731; and Bes, EA37176.

7 Archaeological mission of the University of Cincinnati. Mission 2015, object number 1310. Link: https://www.nytimes.com/2015/10/27/science/a-warriors-grave-atpylos-greece-could-be-a-gateway-to-civilizations.html. Accessed on 12-19-2017.

8 The term "box mirror" corresponds to the terminology adopted in French ("miroir à boîte"). In German, however, it is called Klappspiegel (folding mirror), a denomination which is equally as adequate, because it refers to the manner in which it was used, folding the cover upwards.
} 
opposite, with a clear prevalence of hand mirrors, perhaps, we may posit, due to the hand mirror being more easily represented in two dimensions.

There was a general denomination for mirror, which oscillated between

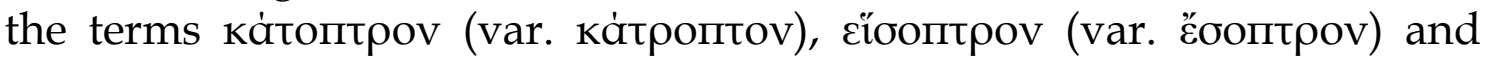
Ëvontpov, without specifying the exact corresponding relationship between term and type of mirror. Some, sustained by a passage of Aristophanes (Nub. 749), understood that the term גopeiov referred to a box mirror with a cover (Ridder 1909: 1425), which is something that is not entirely agreed-upon (Züchner, 1942). As general rule, it seems that in mainland and Aegean Greece the box mirrors succeeded table mirrors without an obvious rupture (Mattusch, 2010: 402); for the Greeks of Magna Graecia, a late Classic and Proto-Hellenistic morphological and ornamental evolution took place, which will not be analyzed here (Vergara Cerqueira 2018).

Box mirrors are composed of a base and a cover; the internal surface of the base, slightly concave, was polished and used to contemplate one's reflected image (Fig. 16b). A unique part of these mirrors, the lid, could be decorated on both sides. On the exterior, it was given ornamentation with an image in relief (Fig. 16a). In a lesser number of cases, the internal part was decorated, engraved, using a very delicate technique. The production of mirrors with relief likely commenced in the mid-fifth century B.C., extending until first quarter of the third century B.C. The technique of Greek carved mirrors, that reached their peak with Etruscan craftsmanship, began at the end of the fifth century B.C., with the caveat, however, that this technique was not unknown in late Egypt, being present, for example, in mirrors of the Late Period from the $25^{\text {th }}$ to $27^{\text {th }}$ dynasties, slightly prior and contemporary to the Greek Archaic Period 9 .

The main Greek production centers that are archaeologically documented are: Corinth, Chalcis, Ionia and, to a lesser degree, Athens (Züchner, 1942), without discounting the contributions of other centers such as Argos (Fig. 01). Magna Graecia assimilated this production, possessing a mirror-production industry in Epizephyrian Locris and Tarentum, where refined mirrors were produced with combinations of bronze, silver and gold plating ${ }^{10}$.

\footnotetext{
9 See Egyptian copper mirror with ivory handle, assembled into a bronze support. Engraved with decoration representing the goddess Mut throned in a sanctuary, laid out above two lines of heiroglyphic inscripitions. London, British Museum, EA51067 (1912, 0608.76). 25th-26th dynasty (?).

10 Box mirror with relief. Origin: Canosa. Taranto, Archaeological Museum, inv. 22436. Züchner, 1942, KS 154, Abb. 43.
} 
Under the influence of Greece and southern Italy, Etruscan bronze mirrors were developed. These were primarily hand-held mirrors, despite other varieties being produced. In contrast to Greece where box mirrors with relief ornamentation predominated, in Etruria these occurred in fewer number. The Etruscans became known for the largescale production of hand mirrors with incised ornamentation representing motifs from Greek mythology, with a lower frequency of motifs related to Etruscan cultural traditions. Eventually, they produced box mirrors in a square format, and it is this form that later became popular in Rome (Ridder, 1909: 1428-29). The Romans inherited their craftsman traditions from the Greeks and the Etruscans, but diversified the materials employed. Pewter and copper were commonly used, or materials of greater value, such as the mirrors worked in silver found at Pompeii.

\section{The mirror in Attic vase painting}

One of the most ancient representations of the mirror in vase painting occurs in an Attic black-figure skyphos from the end of the sixth century B.C. with the judgement of Paris ${ }^{11}$. The painter depicted the mirror in the hand of Aphrodite, so that it became fairly popular "as an attribute and sign of Aphrodite, thereby designated as the winner of the beauty contest" (Balensiefen, 1990: 31). Nonetheless, aside from the association with Aphrodite, the majority of scenes representing mirrors depict everyday domestic context. In the depiction of the domestic context, Attic red-figure vase painters present the mirror in direct association with the female sex. However, this association is not carried out in a homogenous fashion. When we observe the scenes of the gunaikaion, and other kinds of scenes protagonised by figures that refer to the female portion of the body of citizens (and, even more, of its elite), we observe, among the objects depicted, alluding to material and symbolic aspects of everyday life, the mirror is not the most prominent. In contrast, other objects such as baskets, kalathoi, and even the trigonon (harp), figures employed to symbolize the dignity of the citizen women, brides (numphe) or wives (gune) (Fig. 04 e 05) are far more present. In an inventory of more than 50 vases with scenes of musical entertainment in the gunaikaion or of domestic commemorations of marriage, namely the epaulia ${ }^{12}$ scenes, I was

\footnotetext{
11 Attic black-figure skyphos. Athens, National Museum, 12.626. c. 510-500. Cf. Attic black-figure lekythos. Laon, Musée Municipal, 37.894. c. 500-490.

12 Celebration when the bride, after consummating the union, receives relatives and friends bringing presents for the wife's new married life.
} 
able to identify the rarity of the mirror. One of the few exceptions occurs on a hydria by the Kleophon Painter (Vergara Cerqueira 2001: cat. 312) ${ }^{13}$.
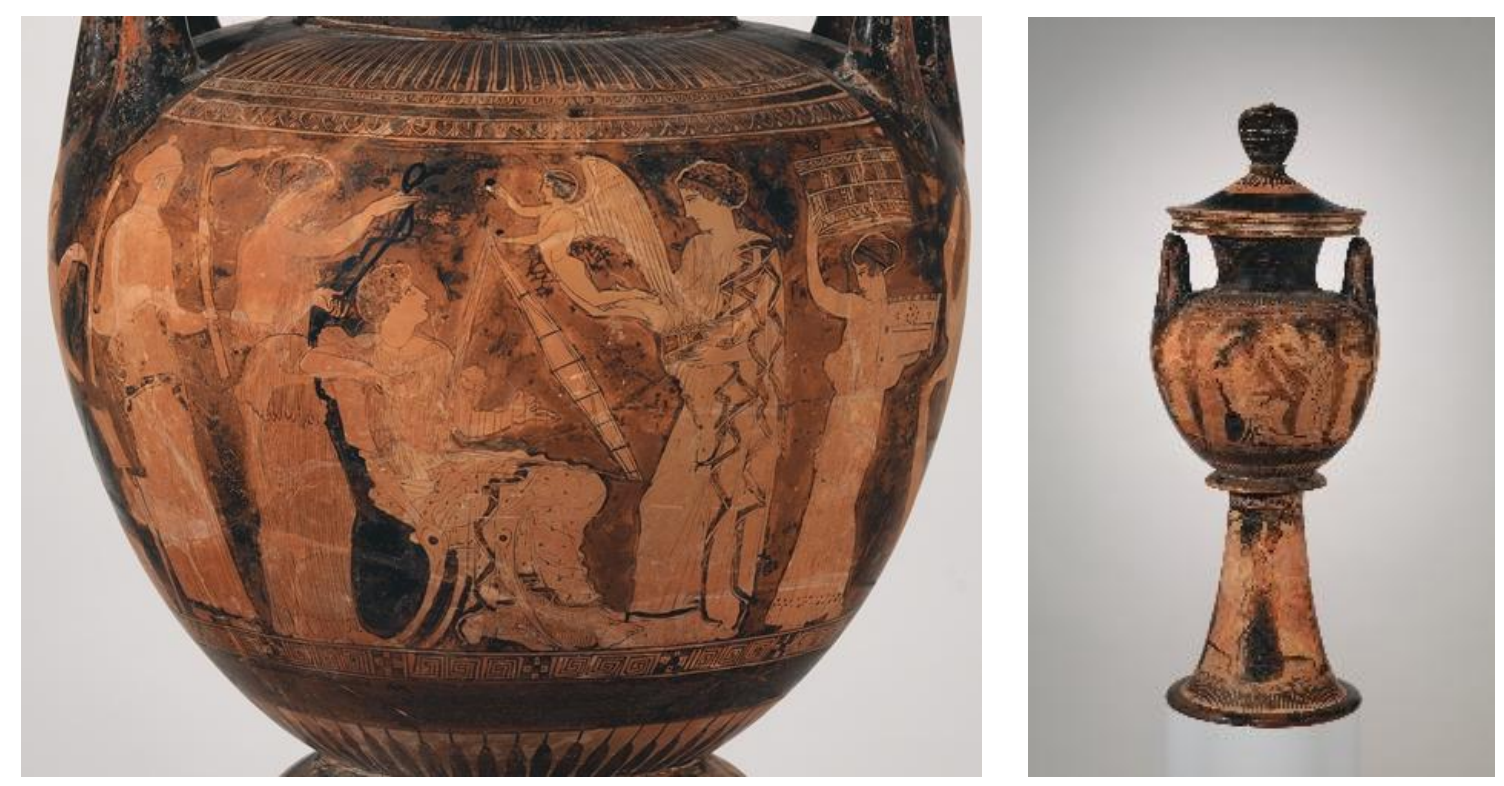

Fig. 4. Attic red-figure lebes gamikos: The Washing Painter. New York, Metropolitan Museum of Art, 16.73. (Owww.metmuseum.org

However, pay attention: we cannot affirm that the mirror was absent from the daily routine of the gunaikaion. It appears indeed in the first quarter of the fifth century B.C. in vases in which the symbolism of the mirror, according to the interpretation of L. Balensiefen, goes beyond its plain association with gender. These scenes depict women preening themselves in front the mirror ${ }^{14}$, "but they cannot be defined as purely images of the gunaikaion or toilette, because in the scenes a general erotic atmosphere prevails, even erotico-dyonisiac" (Balensiefen 1990: 29). Nonetheless, its meaning extrapolates the world of the gunaikaion, a place of female gathering and protection, of dedication to interaction with relatives and friends, where they were occupied with activities necessary to the household economy such as weaving, but also with ludic activities such as musical entertainment (Maffre, 1988. Kunze-Götte, 1957). Moreover, these scenes deal with representations that connote romantic

${ }^{13}$ Attic red-figure hydria. Kleophon Painter (ARV2 1147/62). Munich, Antikesammlung, 6452. c. 430 a.C. Bib.: CVA Munique 5 (Alemanha 20) pr. 231.2 e 9 . In our inventory of musical scenes in the gunaikaion made up of 54 vases, including scenes of musical entertainment (34 vases) and of epaulia (20 vases), the mirror is present in only two vases.

14 1) Attic red-figure lekythos. Brygos Painter (ARV2 384/214). Boston, Museum of Fine Arts, 13.189. c. 480 a.C. 2) Attic red-figure hydria. Alkimachos Painter (ARV2 1608). Athens, Kanellopoulos Collection. c. 470 a.C. The Athenian hydria is considered the first representation of an optically perfectly reflected image in a mirror. 
initiation, compatible with some ritual related to Eros, a concept that becomes fairly common in the iconography of Apulian vases in the second half of the fourth century B.C. (Schneider-Herrmann 1977: 29, 38; 1970).
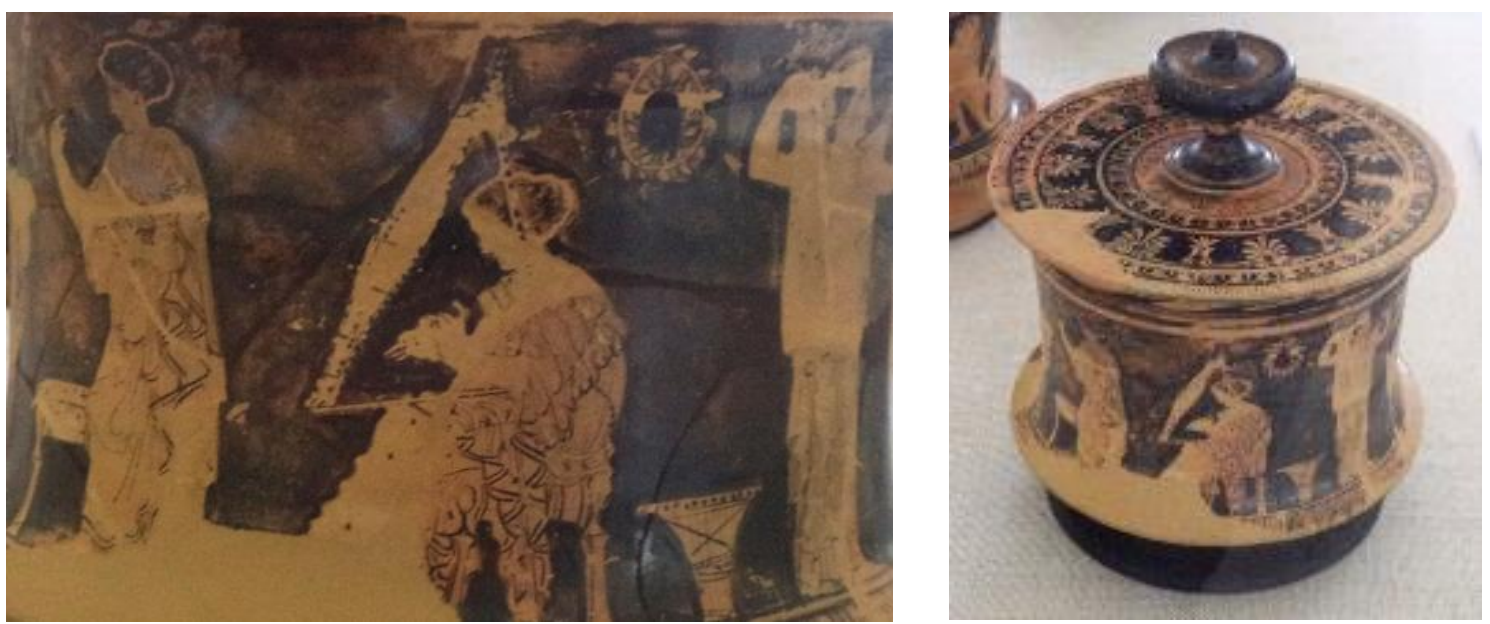

Fig. 5. Attic red-figure pyxis with gunaikaion scene. The Washing Painter. Würzburg, Martin von Wagner Museum, 541. CPhoto: Fábio Vergara Cerqueira (2014)

A special and careful treatment of the mirror can be observed in the iconography of domestic scenes of the female citizen: frequently in scenes of personal aesthetic care with erotic and initiatory connation ${ }^{15}$, but not so common in scenes that portray the dignity of the social condition of the wife, such as the "musical concerts of the gunaikaion", expression of Erika Kunze-Götte (1957), and the scenes of epaulia. Nevertheless, this is a system of representation of material culture realized in the symbolic field. According to the symbolic nature of the scene, the mirror is represented with more or less frequency.

15 1) Scene of hair removal from female intimate body parts: Attic red-figure krater. Dinos Painter. Cambridge (MA), Harvard University, Arthur M. Sackler Mus. Third quarter of the 5th century B.C. (Eros, bent over, shaves a standing naked woman, to the left another woman shaves herself; in the field, a mirror). Kreilinger, 2007, 271, fig. 14a. 2) Naked women viewing herself in the mirror: Attic red-figure kylix. Basel, art market. Circa 460 B.C. (naked woman between louterion and diphros, upon which her clothes rest, viewing herself in the mirror). Kreilinger, 2007, 280, fig. 60. MüM, Kunstwerke der Antike, Sonderlist R, 1977, n. 58. 3) Woman bathing in the louterion: Attic red-figure krater. Painter of the Centauromachy. Louvre. Dresden, Staatliche Kunstsammlungen, ZV 797. Third quarter of the 5th century B.C. (naked woman bathing herself, inside of a basin, upon which is inscribed $\mathrm{KA} \Lambda \mathrm{H}$, accompanied by another naked woman to her left, and a clothed woman to her right, holding a mirror). Kreilinger, 2007, 284, fig. 78. 

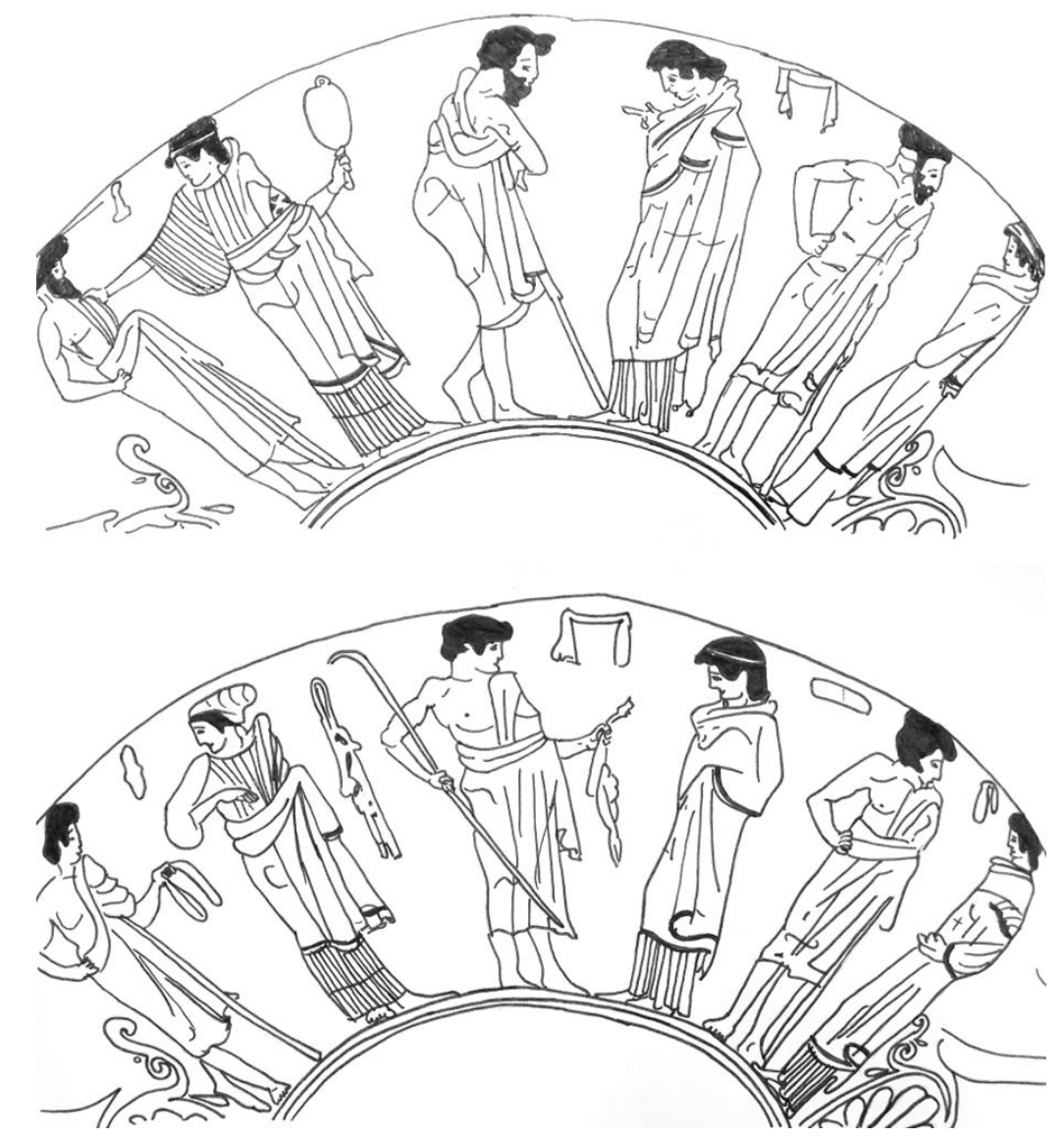

Fig. 6. Adult men and youth visit an ergasterion or porneion. A hetaera holds a mirror: Attic red-figure kylix. Splanchnoptes Painter. Osaka/Sakai, Oka Collection, 13. Source: CVA Japan 2, pr. 32.1-3; pr. 33.1-3. Drawing: Lidiane Carderaro (2018).

When the vase painters move from the domestic space of citizen women to the realm of the hetaerae, feminine attributes such as the basket and the kalathos are practically absent. In their place, the painter represents masculine iconographic attributes and those of hetaerae. On one hand, objects related to the palaestra and gymnasium (the sponge, strigil and diptych) ${ }^{16}$. The presence of such objects suggests that young and adult men brought these items when they retired from athletic or scholarly activities and visited the courtesans. On the other hand, objects such as the aulos (oftentimes visually substituted by its case, the so-called sybene) ${ }^{17}$ and the mirror, frequently depicted in these scenes (Fig. 6). Comparing the repertories of inventoried vases depicting domestic scenes of citizen women with those of brothel, proportionally, the mirror appears four times more frequently in scenes with hetaerae (Vergara Cerqueira, 2001: 515-539).

\footnotetext{
${ }^{16}$ Attic red-figure kylix. Makron. Toledo, Toledo Museum of Art, 72.55. First quarter of the 5th century B.C. CVA Toledo 1 (USA 17) pr. 53-4.

17 Chester Starr (1978) holds that proficiency in the aulos was a differentiating fator for a hetaera given that those who were also auletridai were very much better paid.
} 
However, it is also improbable that the hetaerae in their daily routines did not possess kalathoi and baskets for their daily necessities of producing their own clothing and storage of clothes and belongings. Their absence is symbolic, and the reinforcement of the presence of the mirror is symbolic as well.

The symbolic system, valid for Attic vase painters, organizes a kind of zoning of female iconographic attributes, based on the intersection of gender and social condition. In this system, the mirror, notwithstanding it being an item used generally in the feminine domestic sphere, is visually mobilized as a specific attribute of the social condition of hetaerae. Its erotic symbolism, in this way, is accentuated above other possibilities, such as ritual, mystic or funerary symbolism - elements that are less common in Attic vase iconography, but systematically present in the iconography of Apulian red figure vases of the fourth century B.C.

However, as the realia reveal that the surfaces of Greek mirrors are bearers of a rich iconographic repertory, it is helpful to examine this iconography for a better understanding of the meanings of this object in Greek culture, in this case, the iconography present on mirrors.

\section{Iconography on Greek mirrors: relief or engraved scenes (Chalcis, Athens, Corinth and Ionia)}

The relation of the mirror with the erotic domain of physical sexual pleasure, directly linked to the hetaerae, is a popular theme in Attic vase painting, which influences the iconography on mirror surfaces. A mirror from Corinth provides an illustrative example, replicating scenes of symplegma (explicit sexual intercourse) on the lid, with repoussé decoration on the outer side, and on the internal face using an engraved design (Züchner, 1942: 66, KS 95).

Nevertheless, the amorous association of the mirror is depicted primarily by way of scenes extracted from Greek mythology, which were a predominant inspiration in the iconography of Greek mirrors. Two mirrors produced in Chalcis, in Euboea, exemplify this amorous connotation. In a mirror preserved in Berlin, dating from approximately 375 B.C., the relief on the cover depicts the abduction of Ganymede by Zeus disguised as an eagle (Züchner, 1942, 62, KS 86, Taf. 7) (Fig. 8)18. This same narrative, according to Pliny (N.H. XXXIV.19.17), was the object of attention of a contemporary sculptor: the Athenian Leochares

18 Source: Züchner 1942, 62, KS 86, Taf. 7. (Furtwängler: 400 - 350; Curtius: 350-340). 
who was active between 370 and 320 B.C. He was known in the Ancient World, for the sculptural group depicting Zeus in form of an eagle taking Ganymede away, among other works (Brodersen, Zimmermann 2006: 335). It is very probable that in the representation of the myth reproduced in this Chalcidian mirror reflect the impact of the famous work of the Athenian sculptor, being inspired from it. However, it is not easy to disassociate this theme from an apology for male homoerotic pederasty, that $a$ priori would be fairly paradoxical, given the presupposed feminine supremacy in the "world of the mirror".
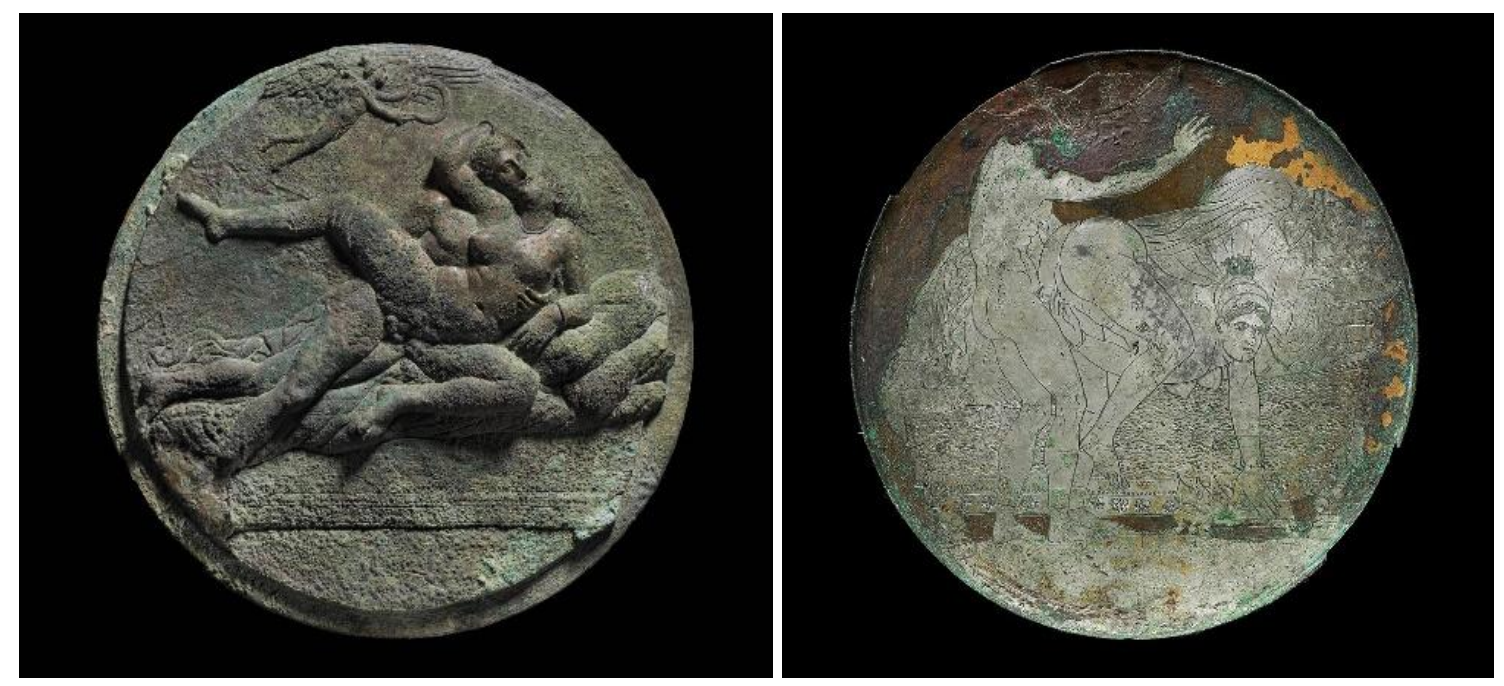

Figures 7a-b. Left: Relief: Eros and sex scene (symplegma). Right: Engraving: Sex scene (symplegma). Box mirror. Bronze. Corinth. Boston, Museum of Fine Arts, RES.08.32c.2 Ca. 340-320 a.C. (Owikicommons (internal scene, incised)

Nevertheless, the amorous association of the mirror is depicted primarily by way of scenes extracted from Greek mythology, which were a predominant inspiration in the iconography of Greek mirrors. Two mirrors produced in Chalcis, in Euboea, exemplify this amorous connotation. In a mirror preserved in Berlin, dating from approximately 375 B.C., the relief on the cover depicts the abduction of Ganymede by Zeus disguised as an eagle (Züchner 1942, 62, KS 86, Taf. 7) (Fig. 8) ${ }^{19}$. This same narrative, according to Pliny (N.H. XXXIV.19.17), was the object of attention of a contemporary sculptor: the Athenian Leochares who was active between 370 and 320 B.C. He was known in the Ancient World, for the sculptural group depicting Zeus in form of an eagle taking Ganymede away, among other works (Brodersen, Zimmermann 2006: 335). It is very probable that in the representation of the myth reproduced in this Chalcidian mirror reflect the impact of the famous work of the Athenian sculptor, being inspired from it. However, it is not easy to disassociate this theme from an apology for male homoerotic pederasty, that a priori

19 Source: Züchner 1942, 62, KS 86, Taf. 7. (Furtwängler: 400 - 350; Curtius: 350-340). 
would be fairly paradoxical, given the presupposed feminine supremacy in the "world of the mirror".

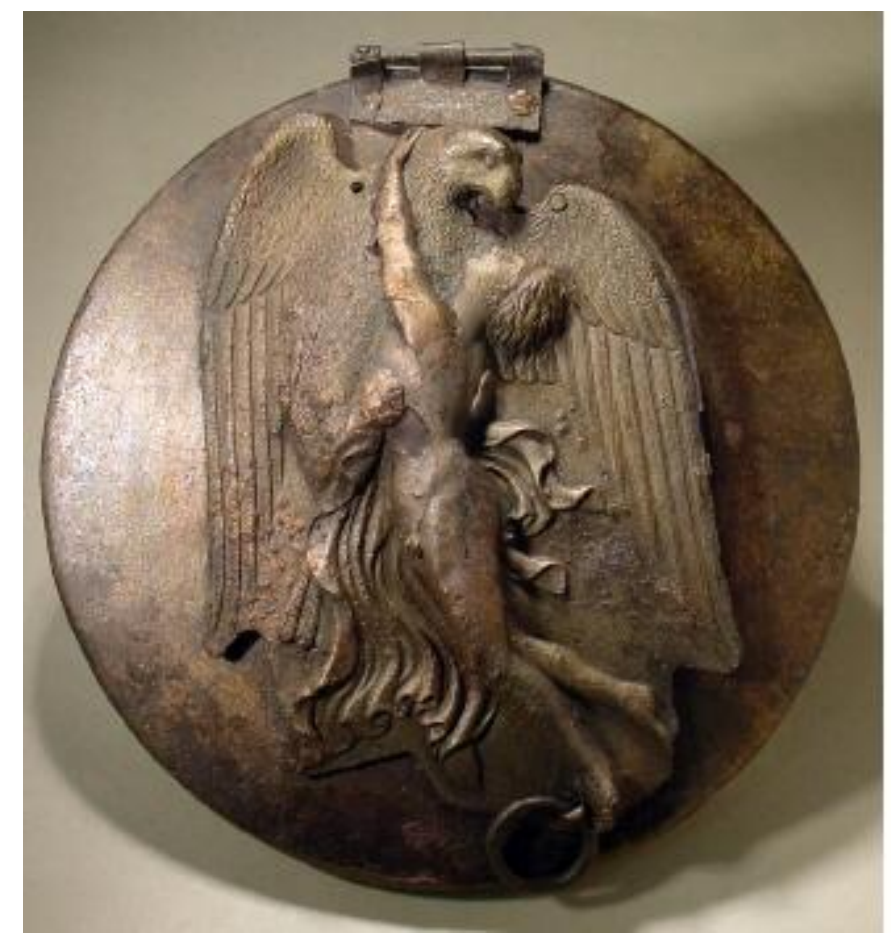

Fig. 8. Zeus (eagle) and Ganymede: Box mirror with cover decorated in relief. Bronze. Produced in Chalcis. Berlin, Antikensammlung, 7928. c. 360-350 a.C. (Züchner). (CPhoto: Antikensammlung, Staatliche Museen zu Berlin. Photographer: Norbert Franken.

The second mirror, from Eretria, dates to the last quarter of fifth century B.C. and is unique in its composition: the two discs are polished on the inner side and their external covers have decoration in relief (Fig. 9a-b). On one of the covers a kissing scene is depicted upon a rocky base with Dionysus resting on his mantle and Ariadne embracing him. The presence of a pair of thyrsoi leave no doubt as to their identification ${ }^{20}$; and the other cover shows a representation of Aphrodite with a preadolescent Eros seated on her legs. A connection between Aphrodite and Dionysus is apparent in the symbolism of this mirror.

The association between Aphrodite and Dionysus is repeated various times in the iconography of the mirror, as on the cover of a mirror in Boston, in whose relief Aphrodite is depicted, leaning on a pillar and giving a rod to a small goose, whereas a flying Eros is nearing in to embrace her. In front of her and to the left is an adult satyr beside a tree

20 This pairing is repeated in other mirrors, such as the Corinthian example in Boston, Museum of Fine Arts, 01.7513, circa 350 B.C. Züchner 1942, 33-34, KS 38, Taf. 19. 
seated upon a panther hide on a rocky base, extending his hand to the goddess ${ }^{21}$.
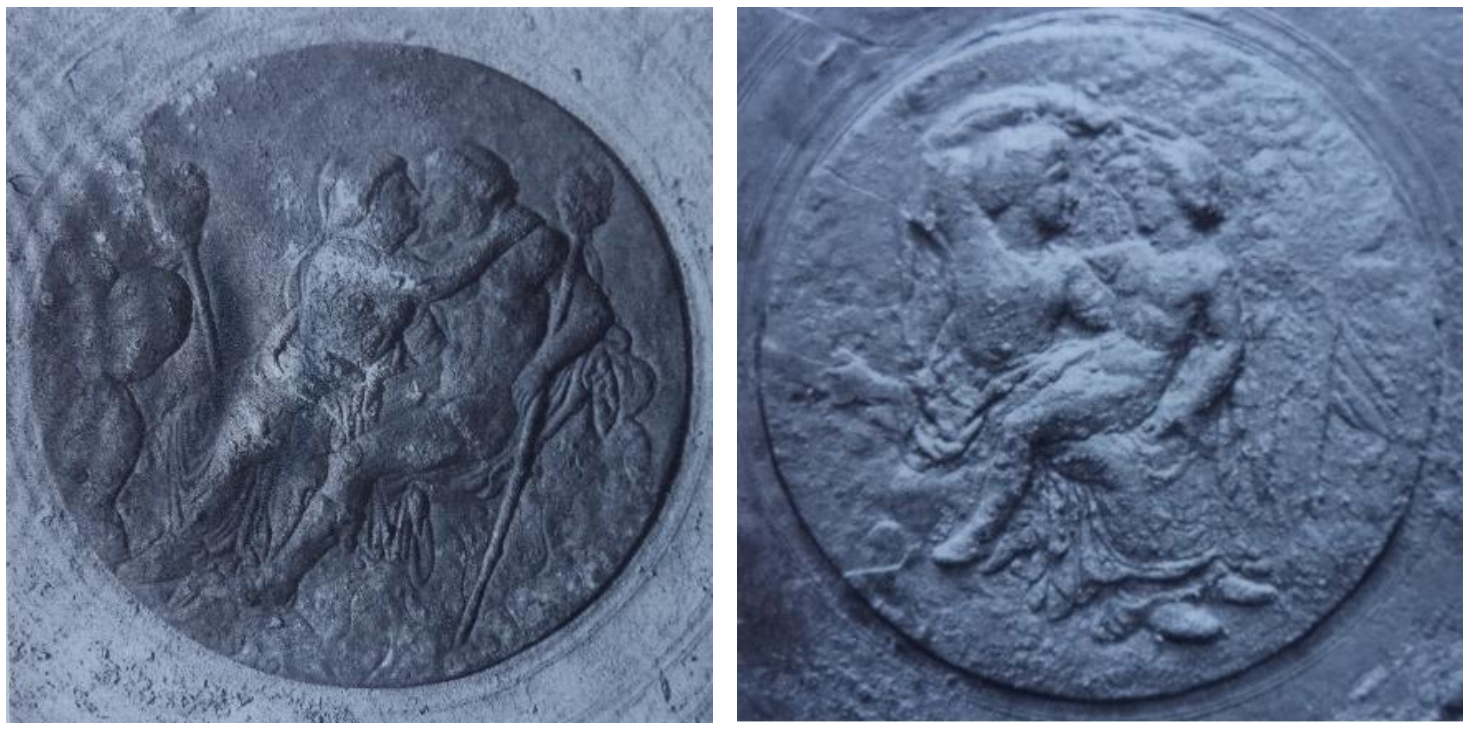

Fig. 9a-b. Dionysus and Ariadne (left). Aphrodite and Eros (right): Dual bronze mirror with cover decorated in relief. Produced in Chalcis. Found in Eretria. Athens, National Museum, 7670 e 7670 a. Last quarter of $5^{\text {th }}$ century B.C. Source: Züchner, 1942, 11, KS 10, Taf. 2.2. and 3.2.

The association between Aphrodite and Dionysus is repeated various times in the iconography of the mirror, as on the cover of a mirror in Boston, in whose relief Aphrodite is depicted, leaning on a pillar and giving a rod to a small goose, whereas a flying Eros is nearing in to embrace her. In front of her and to the left is an adult satyr beside a tree seated upon a panther hide on a rocky base, extending his hand to the goddess 22 .

Despite the thematic variation, primarily inspired by mythological themes and frequently depicting couples in love (Fig. 10) ${ }^{23}$, the

21 Bronze mirror. Undefined origin. Boston, Museum of Fine Arts, 01.7494a-c. c. 320 a.C.

22 Bronze mirror. Undefined origin. Boston, Museum of Fine Arts, 01.7494a-c. c. 320 a.C.

23 1) Boreas and Orithyia: Box mirror with relief. Bronze. Produced in Chalcis. Origin: Eretria. Athens, National Museum, 7416. c. 350 B.C.. Züchner, 1942, 62, KS 87. 2) Selene and Endymion: Box mirror with relief. Bronze. Produced in Chalcis. Origin: Tomb of Demetrias. Athens, National Museum, n./n. Züchner, 1942, 63, KS 88. 3) Hermes and nymph: Box mirror with relief. Bronze. Origin: Corinth. London, British Museum 294 $(1895,1026.1)$. c. 300-270 B.C.. Züchner, 1942, 64, K89. 4) Marsyas and Olympus: Box mirror with relief. Bronze. Produced in Corinth. Origin: Isle of Rhodes. New York, Metropolitan Museum. c. 300 B.C.. Züchner, 1942, 89-90, KS 150, Abb. 104, p. 190. 
predominant figure decorating mirrors, whether Corinthian or Attic ${ }^{24}$, Ionic or Chalcidian, is Aphrodite. Sometimes she is alone, however very often she is with Eros, as in the Chalcidian mirror from Eretria. This is the most common combination, leaving room for variation. In a mirror preserved in Tübingen, probably of Corinthian origin, Aphrodite plays with Eros ${ }^{25}$. In an Ionic mirror from the Hermitage, found on the Taman peninsula in the Black Sea, Aphrodite kisses the young Eros while seated upon a diphros holding him in her lap ${ }^{26}$. In several examples different animals accompany the goddess, whom she plays with, embraces, caresses, feeds and even rides. The birds related to the goddess of love are perhaps the most frequent. In some cases, the animals represented indicate the epithets by which Aphrodite is worshipped.

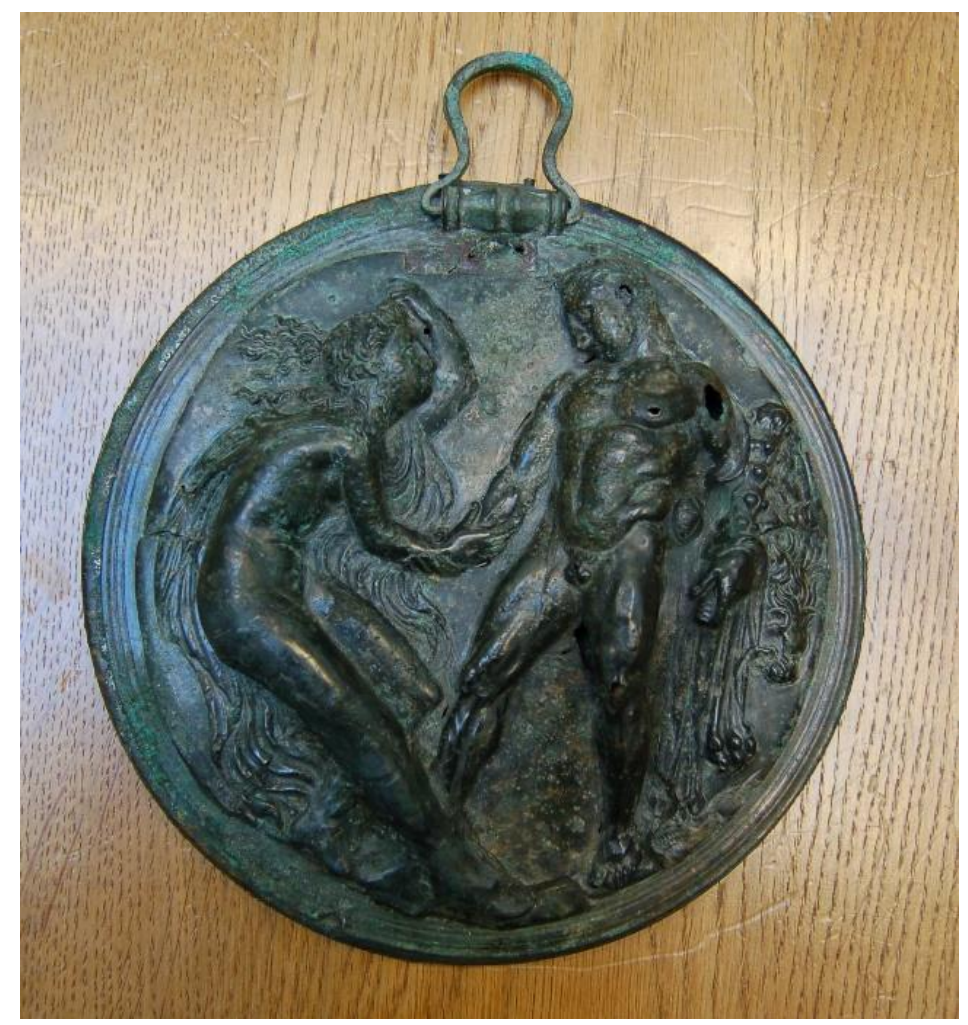

Fig. 10. Heracles and nymph: Box mirror with relief. Bronze. Originating from Corinth. London, British Museum, 293 (1892,0719.4). c. 300-280. CTrustees of the British Museum

${ }^{24}$ Box mirror with relief. Bronze. Produced in Athens. Athens, National Museum, 7678. c. 400 B.C. (Züchner). Züchner 1942, 13 e 222, Abb. 126. (Perdrizet: late $5^{\text {th }}$ century).

25 Box mirror with relief. Produced in Corinth (?). Origin: Athens. Tübingen, Archäologisches Museum der Universität, 210. c. 300 B.C.. Züchner 1942, 14, KS 16, Abb. 2.

${ }^{26}$ Box mirror with relief. Bronze. Produced in Ionia. Saint Petersburg, Hermitage, Tomb of the Priestess, Great Blisniza (Taman peninsula, near Kertsch, Black Sea, Russia). c. 340 B.C.. (Schefold). Züchner, 1942, 215, KS 11, Abb. 121. 
At the National Museum in Athens, a Chalcidian mirror from Eretreia represents one of the oldest preserved box mirrors with a cover and repousse decoration. Here, the goddess gives a bowl of water (?) to a swan upon which she is seated (Fig. 11) ${ }^{27}$. On another mirror, the goddess flies upon a goose, as in a Corinthian example from Paris, discovered in Eretria and dating to the second quarter of the fourth century B.C. (Fig. 12). The goose reinforces the association with Dionysus highlighted above, connoting the sexual impulse.
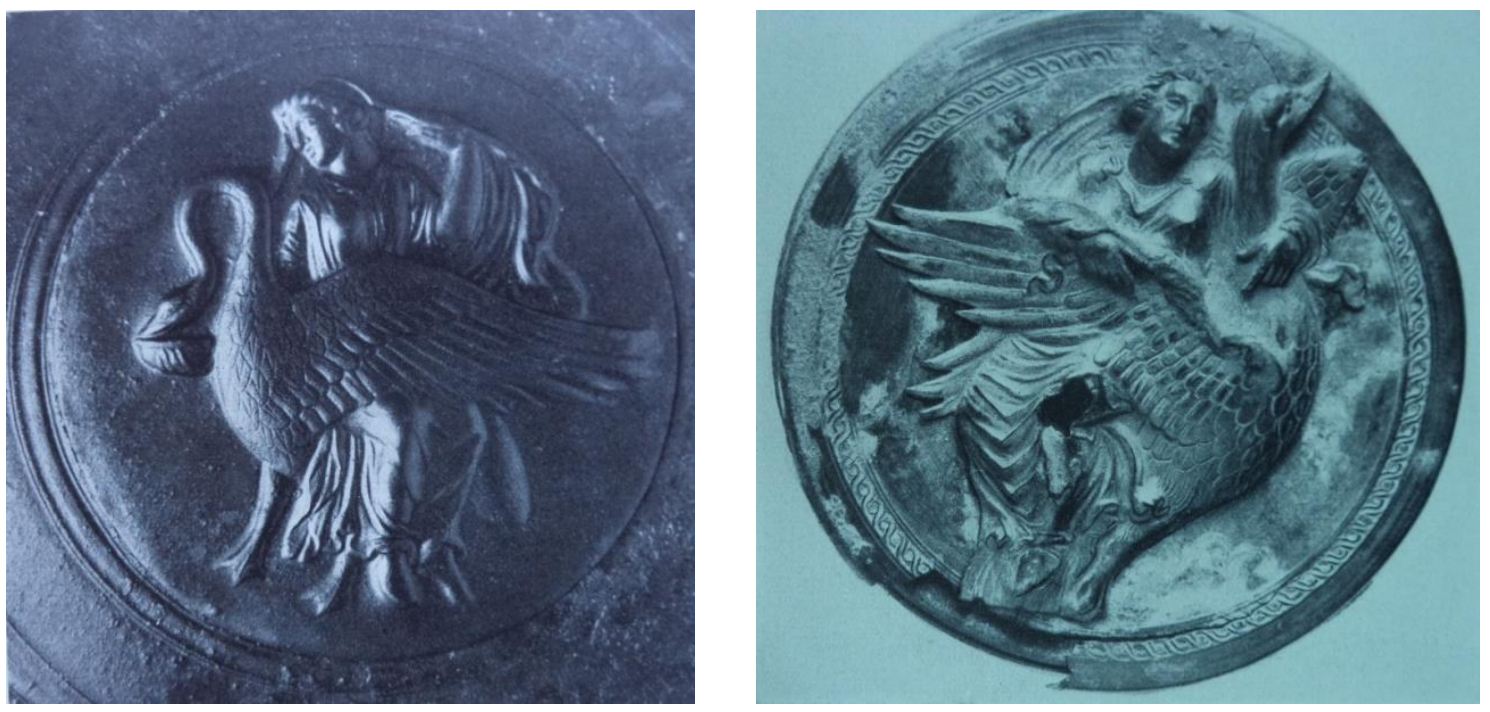

Fig. 11. (left) Aphrodite and swan: Box mirror with cover decorated in relief. Bronze. Produced in Chalcis. Athens, National Museum, 7417. Last quarter of 5th century B.C. Source: Züchner 1942, 5-7, KS 1, Taf. 1, Taf. 2.1.

Fig. 12. (right) Aphrodite and goose: Box mirror with cover decorated in relief. Bronze. Produced in Corinth. Comes from Erétria. Paris, Louvre, 1706. Prior to 375 B.C. Source: Züchner 1942, 7, KS 2, Taf. 5.1.

The case of Aphrodite riding a swan, according to Ursula Knigge (1982: $161)$ is an allusion to the epithet Urania. She sustains this interpretation, based on the Hermitage stele 1876.102, representing Aphrodite upon a swan, in which the goddess is identified in the inscription as Aphrodite Urania. In either of the two cases, whether mounted on a swan or a goose the idea is of flight, and her function of uniting the earthly and celestial realms (Edwards 1984), indicating the function of a goddess that unites (Rosenzweig 2004).

27 It is a dual mirror, with its two covers decorated. On the second mirror (National Museum, 7418, Taf. 3.1), Selene is represented upon a horse. Cf. Collection W. Rome, England (1904). Produced in Chalcis (?). c. 375. (Züchner, 1942, K3). 
Many mirrors depict Aphrodite mounted on a goat. A Corinthian example in Paris ${ }^{28}$ shows the goddess mounted on the animal, galloping to the right, accompanied by its kids. Although its horns are more similar to those of a sheep, the beard and neck make it clear that it is a goat, a sacred animal of the goddess. The scene has plenty of movement: her left hand holding the goat's neck, and in her other hand she holds a flying kerchief, which partly covers her head. In the flying kerchief this image evokes the idea that Aphrodite will fly over the goat. However, more than that, the presence of the kids indicates her quality as the goddess of procreation and fertility. Votive reliefs dedicated to the goddess in her temple situated in the agora in Athens repeat this theme. An example is in the relief Agora S 1797 (Edwards 1984: pr. 17b), showing her popularity as a goddess known as the provider of fertility, which is the reason why she was worshipped so often by free women, brides or wives, as well as by hetaerae, as proven in a silver medallion of the Construction $\mathrm{Z} 3$ of the agora ${ }^{29}$ (Edwards 1984: 68. Rosenzweig 2004: 80-81).

Ursula Knigge (1983: 164-165) defends the thesis that the goat corresponds to the iconographic symbol of Aphrodite Pandemos, an epithet with which the popular goddess was worshipped as the goddess of carnal love. This is opposed to Aphrodite Urania, the epithet of the celestial goddess, chaste, sublime, ethereal, but also of respectful, matrimonial love, symbolized by the swan ${ }^{30}$. Rachel Rosenzweig (2004: 72ff.) and Charles Edwards (1984: 69, nota 64) do not endorse the model of iconographic identification proposed by Knigge. They hold that the

28 Box mirror with relief. Bronze. Produced in Corinth. Origin: Palestrina, Lazio. Paris, Louvre, 1707. c. 375 B.C.. Züchner, 1942, 07-08, KS 4, Taf. 6. Other examples with goats: 1) Athens, National Museum, 7421. Chalcis, Origin: Eretria, c. 350. Züchner, 1942, 0809, KS 5. 2) Berlin, Antikensammlung, 8064.161. Chalcis, imprecise origin (Boeotia or Locris), second half of the 4th century B.C. Züchner, 1942, 09-10, KS 6.

29 The small silver medallion found in Construction Z 3 - part of a compound of various rooms, located next to the Holy Gate, adjacent to the ramparts and inhabitated by prostitutes, many of them being foreign slaves - forms part of the many objects found in this construction that denote the devotion of hetaerae to love goddesses. Not only to Aphrodite, but also to foreign goddesses. Its rich iconography represents the kids of the female goat, evoking the goddess's power over procreation, even more pronounced in the cult of Aphrodite in the Gardens (Rosenzweig, 2004: 78. Lind,1988: 166).

30 Plato, in The Symposium (Symp. 180d-181), establishes this dichotomy, that consists of a philosophical and moral opposition between the two Aphrodites, the distinction that had been revelaed to Socrates by Diotima. In certain terms, it establishes a classification in accordance with the order of logos, of dialetics, submitting the classification between two forms of love (one virtuous, the other non-virtuous) to a rational model. From the religious standpoint, we should be skeptical of this intellectual dichotomy, taking in account the popular beliefs in the melting pot of religious culture. 
goat was common in the two senses of the divinity (Pandemos or Urania), given that the established tradition since the introduction of the worship of Aphrodite in Athens by Aegeus, was that only female goats should be ritually offered in sacrifice. They point out that Urania and Pandemos are simply epithets that focus on different aspects of the same divinity, "celestial" and "of all peoples/demes". In this sense, we should not give too much credit to the dichotomy presented by Diotima to Socrates (Symp. 180d-181), of a vulgar Aphrodite and a celestial Aphrodite, as this dichotomy seems to be merely a rhetorical device used by Plato.

Pandemos, in this way, possessed a dual character. One one hand, the goddess of incontrollable pleasures, as worshipped in Corinth, vulgar if seen in the perspective of the classification proposed by Diotime to Socrates; but also in another sense, as her epithet "of all the peoples" suggests, the goddess that united the inhabitants of the polis into a united political body. It was in this sense that she was worshipped in Athens, together with Peitho (persuasion), worship that is believed to have been introduced by Theseus in the times of the synoecism (Paus. I.22.3). In this sense, she was a political goddess (Burkert, 1977: 242).

In its beginnings, according to Pausanias (I.14.7), Aegeus would have introduced the worship of Aphrodite Urania in Athens; later his son would have adopted the worship of Aphrodite Pandemos (Paus. I.22.3), which would have reinforced her political feature, as a goddess that unites politically. It would be in this way that she would be worshipped as a goddess "of all the demoi" of Attica united in the polis of Athens. This function of a goddess that unites is not in disagreement with her quality of being harmonious and harmonizing, present in the epithet Urania (Edwards, 1984. Rosenzweig, 2004).

From early Athens onwards, the sacrificial animal was a female goat (Plut. Thes. XVIII). Because of this ritual connection, Aphrodite is known also as Aphrodite Epitragia, recalling the story told by Plutarch that, upon Theseus completing a sacrifice, the female goat transformed into a male. The common practice was to sacrifice two white female goats to Aphrodite Pandemos (Lucian Dial. Meret. VII. Theocrit. Epigr. 13).

It is as Epitragia that the goddess is remembered in the mirrors that depict her with a goat. The iconographic scheme had been enshrined by Scopas of Paros (420-350 B.C.), one of the most celebrated sculptors of those times. He created a bronze sculpture of the goddess riding on a goat, addressed to the temple of Aphrodite of Elis, where there would also be a statue of Aphrodite Urania in ivory and gold with her foot on a turtle (Paus. VI.25.1-2), created by the Athenian sculptor Phidias 
(500/490-432 B.C.). It is possible that the representations on the mirrors reflect the influence of the sculpture of Scopas, but it is equally possible that the sculptor of Paros, as well as the artisans of the mirrors drink from the same well.

A variation of the theme of Aphrodite Epitragia with a goat can be found on a mirror made in Corinth and found in Eretria, which is kept at the Antikensammlung in Berlin (Züchner, 1942, 10, KS 7). It represents the goddess riding a female goat between Eros and Pan (Fig. 13), once again moving towards the realm of Dionysus, a domain of uncontrollable desire.

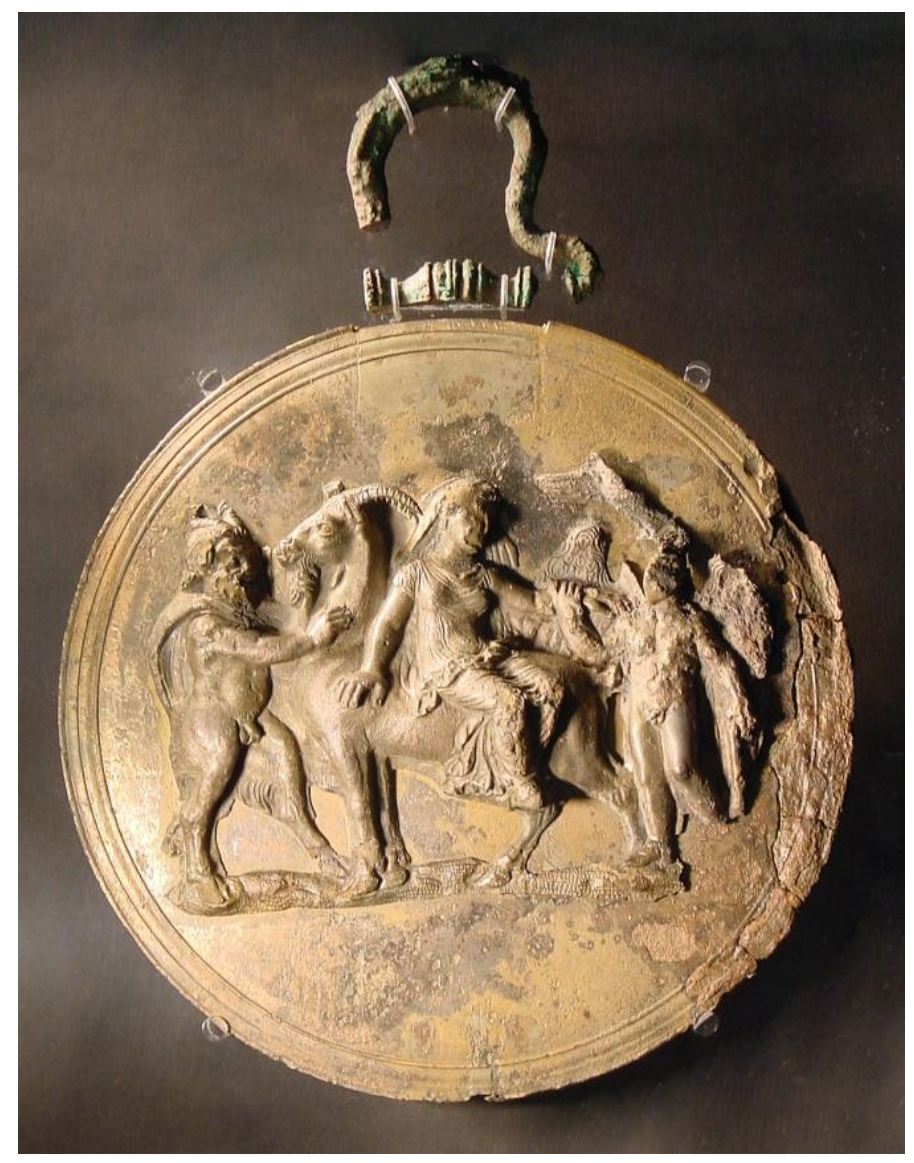

Fig. 13. Aphrodite Epitragia (on a female goat), between Pan and Eros: Box mirror with relief. Bronze. Berlin, Antikesammlung, 8393. Corinth, Eretria (?), c. 375. CPhoto: Antikensammlung der Staatlichen Museen zu Berlin - Preußischer Kulturbesitz - Photographer: Norbert Franken

The goat is a sacred animal shared by Aphrodite and Dionysus, and both receive it as a sacrificial offering in rituals dedicated to them ${ }^{31}$, so that here one verifies the association between these two divinities. This

31 On the altar of Aphrodite in the agora of Athens, numerous remains of goats were found, sacrificed by the general population or perhaps by the public authorities (Rosenzweig 2004: 78). 
association is strongly evident above in the Chalcidian double mirror of Eretria (Fig. 09), which probably encompasses the mystic-religious significance of the object. Consequently, it extrapolates the symbolism of beauty, connoted primarily in the figure of Aphrodite. It means more than that! The figures of the two kids allude to fertility, one more an attribute of the goddess that brings her closer to Dionysus. Now, it is very significant to observe that themes related to these two divinities are, respectively, the first and second most common themes expressed in the iconography of box mirrors. M. Nilsson (1995, p. 377) points out that a mixture of worship of Aphrodite and Dionysus occurred during the Aphrodisia festival in Corinth, something that gave a more religious character to the festivity, which otherwise could be viewed from a less sacred point of view, given the effusive participation of the hetaerae in the celebrations throughout the night. This association leads us to the realm of worship, of practices of erotic initiation that were realized under the auspices of these divinities. They were worshiped as Aphrodite Antheia and Dionysus Antheios, protectors of ever blossoming life, under whose power secret initiation rituals were carried out with young women, in which Eros would act as mediator between the two divinities (SchneiderHerrmann, 1977, 29).

In a lesser number of mirrors, the decoration strays away from the erotic symbolism represented in scenes from mythology, and returns to the representation of the daily practical function of the mirror, as an object in the feminine toilette. An engraving on the internal surface of a Corinthian mirror in Berlin shows us a woman or nymph washing her hair in a basin with water that springs from a fountain while being observed by the goat-god Pan. This image merges the representation of the pragmatic function and the added symbolism of the mythological figure of Pan. In the external scene, a partial repetition of the scene occurs: a woman washes her hair with water that springs from a fountain, next to the basin, slightly below a head of Pan incorporated into the structure of the fountain (Fig. 14).

A purely "gender scene", connected with feminine toilette, occurs on an Ionic mirror in Paris, with two nude women washing and dressing their hair next to a tub (louterion) ${ }^{32}$. In contrast to the nudity of the Ionic and Corinthian mirrors cited above, a Corinthian example in New York depicts two women, elegantly dressed, making their toilette. The woman seated on the left has an alabaster flask in her right hand containing oil or perfume and in her left hand she grasps a mirror, holding it close to

32 Box mirror with relief. Bronze. Produced in Ionia. Origin: Tanagra. Paris, Louvre, 1713. Second quarter of the $4^{\text {th }}$ century B.C. 
another woman, seated on the right, so that she may see herself while she dresses her hair (Fig. 15).
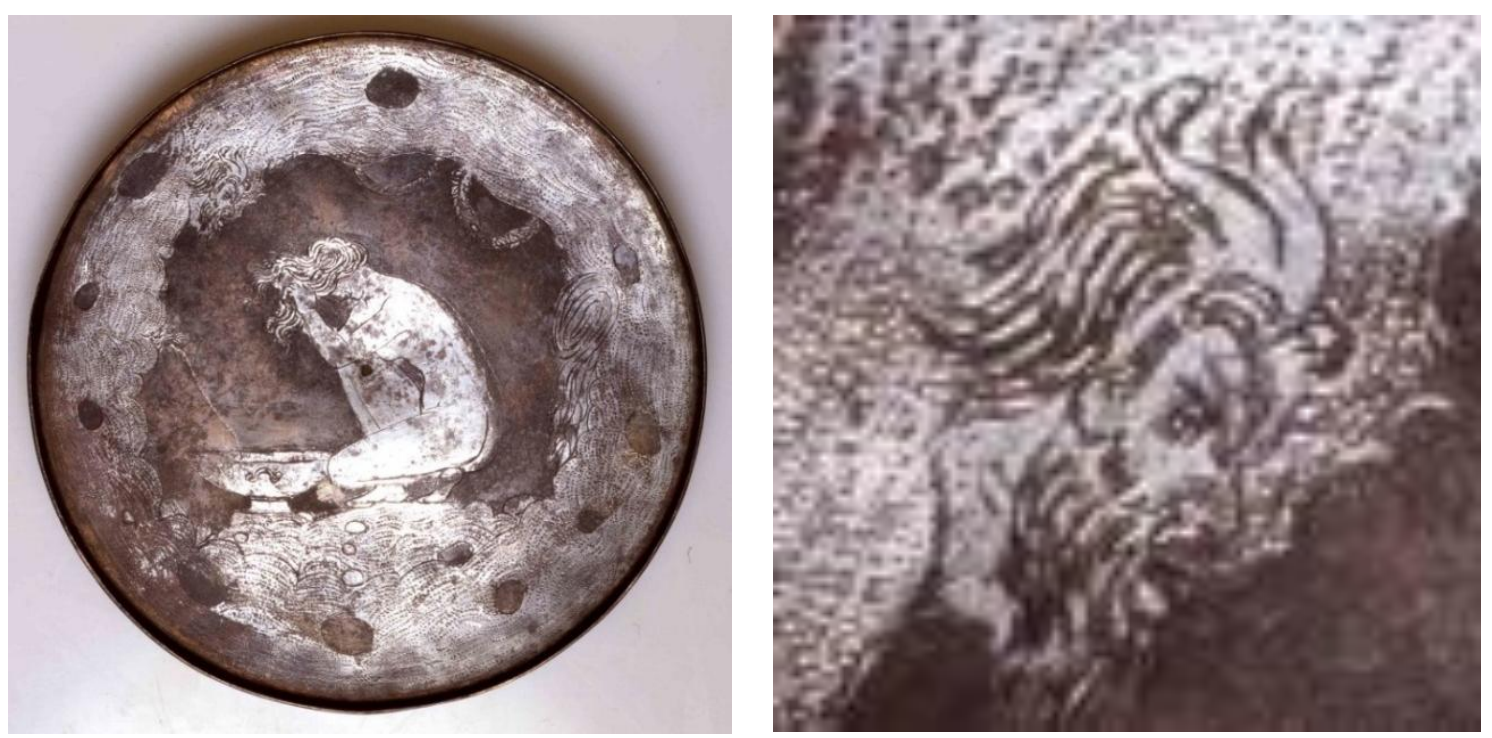

Fig. 14. (left, detail) Woman washes her hair next to a small tub: Box mirror with decoration in relief (cover) and engraving (interior surface). Bronze. Produced in Corinth. Found in Athens. Berlin, Antikesammlung, 8148. c. 280 a.C. (CPhoto: Antikensammlung der Staatlichen Museen zu Berlin - Preußischer Kulturbesitz Photographer: Johannes Laurentius
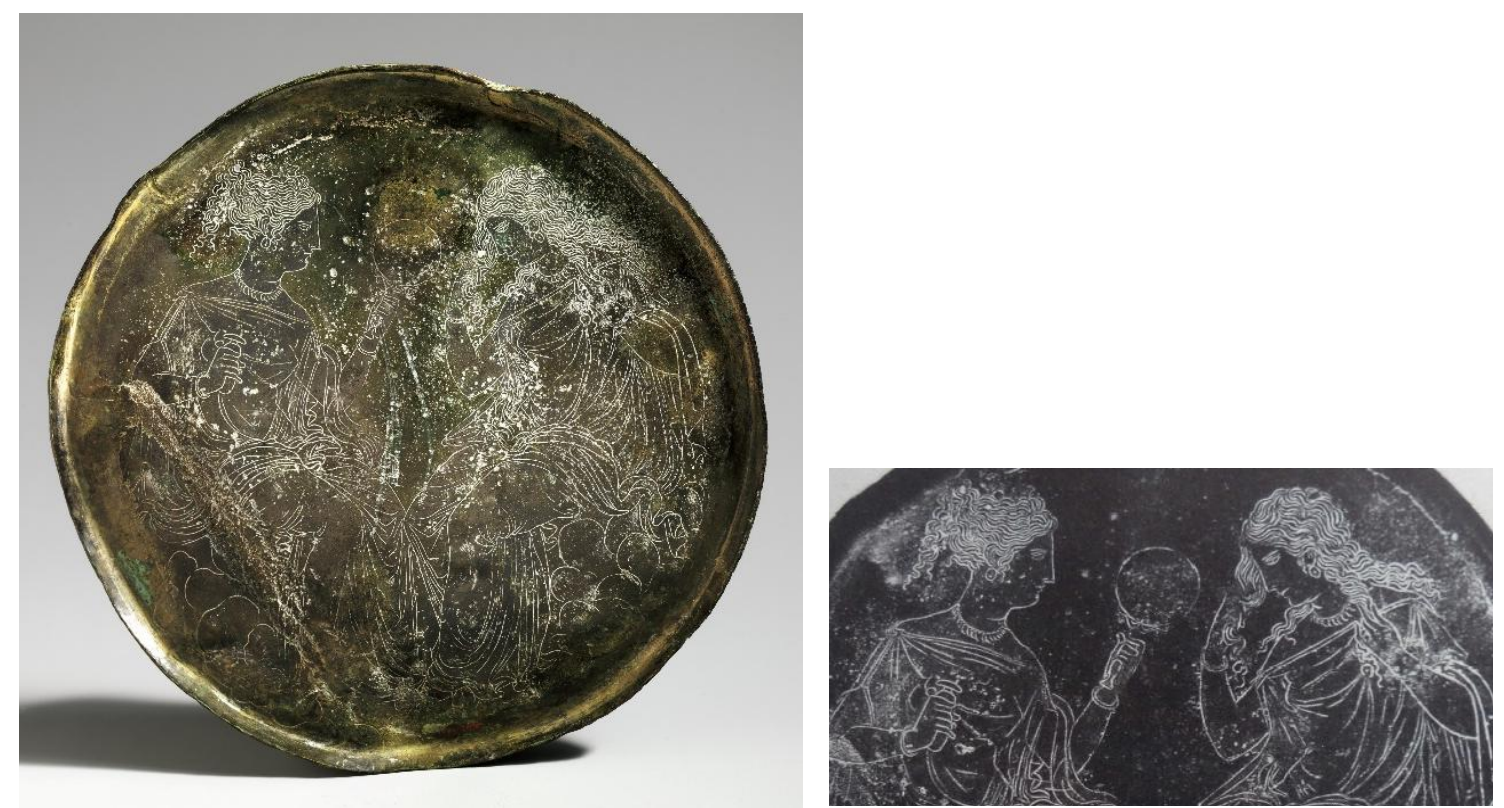

Fig. 15. (left, detail) Two elegantly dressed women, one holds a mirror and a flask, the other dresses her hair, looking at herself in the mirror: Bronze mirror with interior surface decorated with engraving. Produced in Corinth. New York, Metropolitan Museum, 17.190.2073. Second quarter of the 4th century B.C. (Schefold: 360-50 B.C.). Source: Züchner, 1942, p. 99-100, KS 164, Abb. 98. Cwww.metmuseum.org 
The Corinthian mirror in New York shows the mirror in the mirror, indicating its use by women as a feminine personal care utensil. In this case, we probably see its use by women of high social status, "citizenwomen". On an exceptionally well preserved box mirror in Brussels we see the goddess Aphrodite viewing herself in a mirror on the cover decorated in relief (Fig. 16a). This gesture indicates her attribute as the goddess of beauty. Here, Aphrodite is not only a divinity that provides love - she herself seduces with her beauty. She is in the presence of Hermes, whose love she yields to, in exchange for her sandal. They are sitting on a rocky base, suggesting consenting love, at the same time that an exuberant, adolescent Eros draws near with a ribbon, commemorating the union.
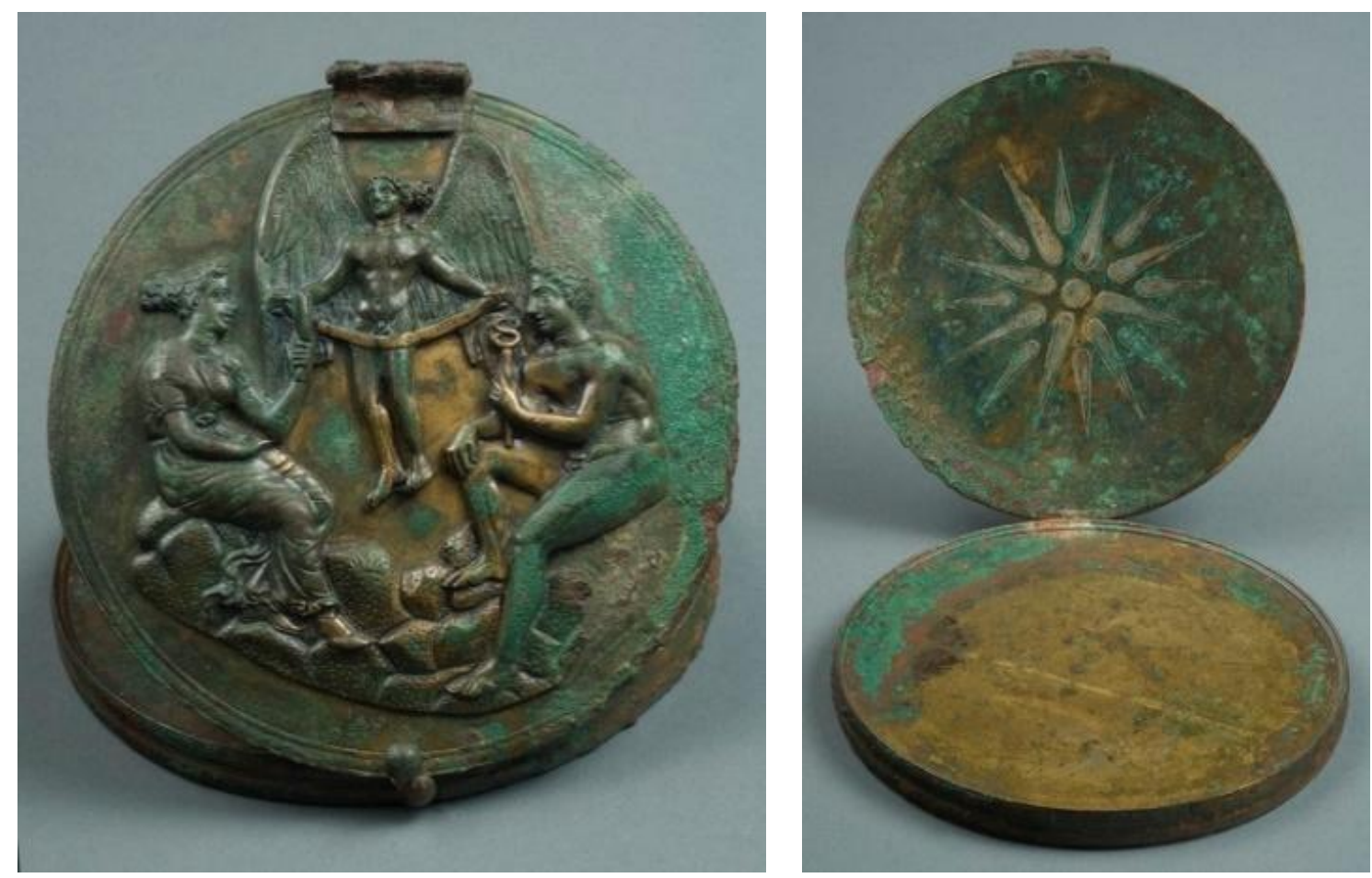

Fig. 16a-b. Aphrodite, Hermes and Eros (left). Star (right): Box mirror, in bronze, with original structure well preserved, consisting of polished disc, hinged to a lid, with engraving in inner side (star) and repoussé decoration on the cover. Produced in Corinth. Third century. Brussels, Musée du Cinquantenaire, R.1266. @MRAH-KMKG

This mirror may resonate with the version known by Cicero, in which Eros was born of the union between Aphrodite and Hermes (and not of that between the goddess and Ares) (Cic. N.D. 3.22.59)33. Upon seeing the interior surface (Fig. 16b), we are surprised by an ornamental engraving that recalls a large star, which we can imagine to be resplendent. It is

33 "(...) was engendered from the sea-foam, and as we are told became the mother by Mercury of the second Cupid". (...) altera spuma procreata, ex qua et Mercurio Cupidinem secundum natum accepimus. (Rackham) 
important to remember that according to one of the two versions reported by Hyginus the constellation Aquila originated from the eagle that was placed in the sky by Hermes in gratitude for having brought the sandal of Aphrodite in an act of thievery (at the request of Zeus) while the goddess was bathing in the Achelous River (Hyg. Astr. 2.16) ${ }^{34}$. In this mirror, the erotic symbolism and the pragmatic usage meld into one image.

\section{Final Considerations}

The studied mirrors date from a period that extends from the last quarter of the fifth century B.C. to the first quarter of the third century B.C., thus close to a century and a half. The Athenian examples are the oldest ones, but they do not provide many examples for the fourth century B.C.. The Chalcidian mirrors begin at the end of the fifth century B.C. and continue to be produced throughout the following century. The Ionic mirrors are concentrated in the fourth century B.C., whereas the Corinthian ones present a longer series, moving into the first decades of the third century B.C. It is interesting to observe, in this chronology, that most of this period corresponds to the floruit of Apulian red-figure vases, manufactured primarily in Tarentum, whose activity extends until 300 B.C. approximately, whereas the studied mirrors date until 270 B.C. The similarities are limited, however, solely to chronology. In reference to the iconography and its implications respecting the "world of the mirror" there are no corresponding similarities, except in a few isolated cases.

Among the thematic variations in the iconography of mirrors from the four main Greek centres (Chalcis, Athens, Corinth and Ionia) a coherent set highlight the motif of love. This set has four different orders of meaning in varying scale: practical usage (feminine toilette), erotic symbolism related to prostitution (explicit scenes of sexual relations), general love symbolism (mythological couples) and magic-religious

34 "Mercurius stirred by Venus's beauty, fell in love with her, and when she permitted no favours, became greatly downcast, as if in disgrace. Jove [Zeus] pitied him, and when Venus was bathing in the river Achelous he sent an eagle to take her sandal to Amythaonia of the Egyptians and give it to Mercurius. Venus, in seeking for it, came to him who loved her, and so he, on attaining his desire, as a reward put the eagle in the sky [as the constellation Aquilla]." Nonnulli etiam dixerunt Mercurium, alii autem Anapladem pulchritudine Veneris inductum in amorem incidisse; et cum ei copia non fieret, animo, ut contumelia accepta, defecisse. Iovem autem misertum eius, cum Venus in Acheloo flumine corpus ablueret, misisse aquilam, quae soccum eius in Amythaoniam Aegyptiorum delatum Mercurio traderet; quem persequens Venus ad cupientem sui pervenit. Qui copia facta, pro beneficio aquilam in mundo locavit. (Grant) 
symbolism (love initiation ceremonies, related to Aphrodite, Eros and under the protection of Dionysus). Quantitatively, the latter two modalities of love symbolism predominate. On the other hand, as regards the Attic vases from the late sixth to early fourth century B.C., the connection of the mirror with hetaerae, and consequently with sexual pleasure obtained via prostitution, prevails. This was typical of the way they worshipped Aphrodite in Corinth. In her sanctuary in this town, it was common for hetaerae to offer up their mirrors to the goddess, upon abandoning their profession due to advanced age.

Within the spectrum of meanings contained in the iconographic repertoire of the Greek mirrors, erotic symbolism oscillates between two approaches: scenes with mythological or human characters. Among the love scenes with human characters, there is interest in representing explicit sex, evoking the social milieu of hetaerae. Among the scenes with mythological characters, the couples depicted are varied: Hermes and nymphs, Hercules and nymphs, Boreas and Orithyia, Selene and Endymion, or homoerotic couples such as Zeus and Ganymede, Marsyas and Olympus. However, there is a notable predominance of scenes involving Aphrodite, followed by those involving Dionysus. The scenes with Aphrodite occur in the four main Greek mirror industries. In the Athenian productions that focus on love such images very often portray Aphrodite and Eros, or Dionysus and Ariadne. The Chalcidian and Ionian productions mainly depict variations in mythological couples. Scenes in which nymphs symbolize the feminine erotic content become more common towards the late fourth and early third century. It should be noted that beyond a greater quantity and longer chronological period of production, the Corinthian workshops also display wider a thematic variety. It is precisely among Corinthian mirror manufacturers that a remarkable interest in representing feminine personal care can be observed, varying between nude and dressed women, including probable hetaerae as well as citizen women. It is the Corinthian mirror that represents, in considerable quantity, scenes of symplegma (explicit sex). Known in the Ancient World as the mecca of pleasures and prostitution, it is plausible that this context would have influenced certain preferences in Corinthian mirror iconography.

It is relevant to present the counterpoint of the iconography of the mirror in Apulian vase painting. That the typical attribute of the mirror in Apulian iconography is its general mystic symbolism, based on a complex belief system, becomes evident through a systematic analysis, interpreting the series that point to their varied uses and symbolic meanings. On the one hand, the many uses: feminine toilette, erotic 
initiation ceremonies, funeral rites, or worship of Aphrodite or Eros. On the other, the many meanings, the primary function of reflecting one's image, the symbol of a young woman prepared for marriage, an attribute of Aphrodite, a mystic oracular symbol, Dionysian funerary symbolism, or a symbol of erotic initiation ritual.

As regards this varied mystic symbolism, we can observe four different expressions of belief. Firstly, of beliefs related to romantic expectations anchored in the auspices of Aphrodite and Eros. Secondly, beliefs related to the afterlife, supported by the association of these divinities with Dionysus. Thirdly, perhaps as a direct result of the second, the magic beliefs in the oracular powers of the mirror, through which the souls of the dead people could express themselves. Fourthly, of beliefs of mysticreligious nature, in which the mirror appears as an item used in the worship of Aphrodite and Eros (Vergara Cerqueira 2018).

A reasonable distance can be seen in relation to Attic iconography, both in vases as well as mirrors. If, in the Apulian vase painting the mysticreligious meanings predominate, in the Attic repertories love prevails. Erotic pleasure (Kuzmina 2013: 158) or protection of married life prevail, albeit this is not treated homogeneously. On the vases, there is a strong symbolic association with hetaerae and the kind of sexual pleasure the men seek with them. On the mirrors, in turn, the representations of Aphrodite and Dionysus predominate, alternating with several mythological approaches of love couples. It is true that it is possible to identify a common linkage between the Corinthian mirrors and the Attic vase painting, connecting the mirror with erotic physical pleasure.

However, all is not dissimilar between Attic and Apulian iconography. There is a point of convergence in the ritual meaning of the mirror, conditioned by its possible use in rituals dedicated to Aphrodite and/or Eros. Such rituals draw them closer to the realm of Dionysus. Namely, to a realm of beliefs and veneration shared among these divinities, such as at the Aphrodisia festival of Corinth. This suggests usage of mirrors in the worship of these divinities, which could encompass religious initiation rites of erotic meaning.

The contrast between the iconography of mainland Greece and that of Magna Graecia (we should remember that the Greek mirrors iconography analyzed here is contemporaneous with the Apulian vases) reveals yet another relevant point to be considered. The studies of mirrors in Ancient Greece generally allude to the mirror as "women's business" (Vernant 
1989: 118) ${ }^{35}$, or even more, to the mirror as an object reserved for women and prohibited for men, to the point that for a man to look at himself in the mirror would be embarrassing. To summarize: an object of the "monde des femmes" (Frontisi-Ducroux, Vernant 1997). Nevertheless, Apulian vase painting presents varying situations depicting the mirror in relation to figures of the male sex (Vergara Cerqueira 2018). In love initiation rituals, the young man must look at himself in the mirror. In funerary contexts, considering the beliefs and funerary practices involving the mirror, it is an object which both men and women need to manipulate. It is impossible to deny that these situations generate a certain amount of skepticism in relation to the recurrent affirmation that the mirror, in its utilitarian and symbolic contexts, is exclusively feminine. For Cassimatis (1998: 301) "one can no longer reason according to the traditional criterion mirror=woman" based on varied evidence indicating masculine uses and meanings of the mirror ${ }^{36}$.

The repertory of mythological erotic couples represented on the mirrors also merits further attention. I think that they can contribute to reflection upon the issue raised above. If mirrors were, in fact, an object exclusive to the "realm of women", linked to the seduction demanded from women by men (Frontisi-Ducroux in Frontisi-Ducroux, Vernant 1997: 100. Vernant 1989: 118) why would there be depictions of homoerotic couples? Couples in which the pleasures and seduction involved are only masculine! Even if the Chalcidian mirror representing Zeus and Ganymede (Fig. 08) reflects on the artistic influence of the contemporary sculptor Leochares, there is a masculine view in it, a viewpoint of an erastes who identifies himself with Zeus disguised as an eagle, when he kidnaps the beautiful ephebe and carries the desired eromenos to his kingdom.

Another doubt: can a single, uniform "realm of women" be conceived of, disregarding the difference of status between hetaera and citizen-wives? Are the realm of women represented with dignity in their domestic personal care (Fig. 15) and the realm of the hetaerae and their sexual services treated homogeneously in mirror iconography? In other words:

\footnotetext{
35 “Dans la vie quotidienne des Anciens le miroir est par excellence chose de femmes. Il évoque le rayonnement de leur beauté, l'éclat de leur séduction, le charme de leur regard, de leurs cheveux bouclés, de leur teint délicat."

36 Beyond the evidence of Apulian vase painting, Cassimatis (1998) considers, as a testimony of masculine meanings of the mirror, the archaeological evidence of funerary context (p. 298-299) and the literary evidence (p. 300). She highlights, concerning the masculine uses of the mirror, Diogenes Laërtius (II.33.9; III.39.4), regarding advices given by Aristotle and Plato, and Plutarch (Dem. 11.1.9), on the large mirror of Demosthenes.
} 
would the scenes of symplegma, such as in the Corinthian mirror in Boston (Fig. 07), be at the service of a masculine or feminine view of pleasure? Could the women in the Boston mirror, produced in the Ancient Greek capital of prostitution, penetrated by their sexual partners, be "citizenwomen" in the pleasures of married life? I tend to think that it is most probable that it is a man having fun with a hetaera. Historiography, as a matter of fact, conditioned me to think this way ${ }^{37}$. However, in this case, does the mirror continue to serve a feminine view? Well, it could have been the mirror of a hetaera! An example could be the mirror that the famed courtesan Lais of Corinth, "The Beautiful" (fl. 425 B.C.), gave in offering to Aphrodite in the goddess's sanctuary in her homeland ${ }^{38}$. Or as the case of countless other mirrors referred to in the votive epigrams. If the perspective were masculine, how would the affirmation of the mirror as an exclusive women's object stand? The answers are difficult. I leave these questions open, as stimulus for further investigation to be carried out regarding this engrossing object and its representations.

I ask myself: could the answer regarding the meaning of the mirror be found in the dual character of Aphrodite, as the goddess who unites? The goddess who bridges social barriers, goddess of all women (hetaerae, slaves, wives, brides), goddess of all kinds of love, of uncontrollable desires or planned love, of heterosexual love and even of homoerotic love. The divinity of fertility, a quality shared with Dionysus (the power attributed to Aphrodite Antheia, partner of Dionysus Antheios). The goddess of women that are married and want to become mother, goddess of the seductive beauty of courtesans, goddess of carnal sexual pleasure. The general meaning, that is found throughout the axiology of the mirror in Greece links it to a tribute to eroticism, a sense of eroticism that unites the different eroticisms separated by social barriers, an eroticism in which Pandemos and Urania combine into one. Here lies the huge social power of the "mirror" as an object, which symbolizes the power of eroticism - of pleasure, of desire, of love - uniting what society separates.

\footnotetext{
37 However, recent authors, as Ulla Kreilinger (2007), do not endorse the traditional criterion "naked women = hetaerae". The iconography of mirrors, as well, make us suspicious of the validity of the criterion "well dressed women = citizen women".

38 Plat. Anth. Pal. VI.1 (Votive Epigrams): "I, Lais, whose haughty beauty made mock of Greece, I who once had a swarm of young lovers at my doors, dedicate my mirror to Aphrodite, since I wish not to look on myself as I am, and cannot look on myself as I once was."

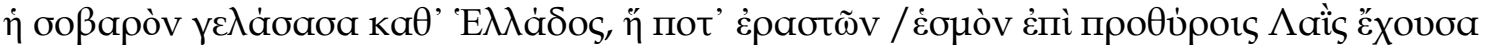

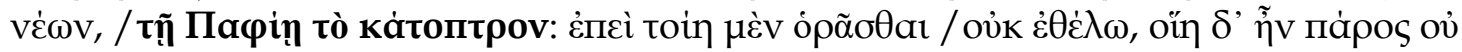

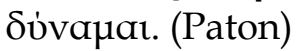




\section{Acknowledgements}

For the research funding, I thank the Humboldt-Foundation, the Coordenação de Aperfeiçoamento de Pessoal de Nível Superior / Capes, Ministério da Educação, Brazil, and the Conselho Nacional de Desenvolvimento Científico e Tecnológico / CNPq, Ministério da Ciência e Tecnologia, Brazil. For the academic cooperation, Dr. Reinhard Stupperich (Heidelberg University), Dr. Corinna Hoff, Dr. Ingrid Krauskopf (Heidelberg University), Dr. Claude Pouzadoux (Centre Jean Bérard, Naples), Dr. Airton Pollini (Univeristy of Mulhouse) and Dr. Manuel Albaladejo de Vivero (University of Valencia). For the result facilities, the Institute of Classical Archaeology, Heidelberg University, and the Centre Jean Bérard at Naples, linked to the French School at Rome. For the translation and revision, respectively José A. Curbelo and Priscilla Ulguim.

\section{Ancient Sources}

CICERO. De Natura Deorum. With an English translation by $\mathrm{H}$. RACKHAM. In twenty-eight volumes. Loeb Classical Library. London: William Heinem Ann Ltd., 1967.

HYGINUS. The Myths of Hyginus. (Including the Fabulae and the second book of the Poetica astronomica.) Translated and edited by MARY GRANT. Transl. By Mary Amelia Grant, Lawrence: University of Kansas Press, 1960.

PLINY THE ELDER. The Natural History. With translation of John Bostock. Londres: Taylor and Francis, 1855.

PLINY THE ELDER. Naturalis Historia. Karl Friedrich Theodor Mayhoff (ed.). Lipsiae: Teubner, 1906.

THE GREEK ANTHOLOGY. With an English Translation. Transl. by William Roger Paton. London: Loeb, 1916-1918. 


\section{Bibliographyc References}

BALENSIEFEN, Lilian. Die Bedeutung des Spiegelsbildes als ikonographisches Motiv in der antiken Kunst. Tübinger Studien zur Archäologie und Kunstgeschichte, Band 10, Tübingen: Ernst Wasmuth Verlag, 1990.

BRODERSEN, Kai; ZIMMERMANN, Bernhard. « Leochares », Metzler Lexikon Antike, $2^{\mathrm{a}}$ ed., Stuttgart - Weimer: Verlag J.B. Metzler, 2006, p. 335.

BURKERT, Walter. Griechische Religion. Stuttgart, Berlin, Köln, Mainz, 1977.

CASSIMATIS, Hélène. Le miroir dans les représentations funéraires apuliennes. Mélanges de l'École française de Rome. Antiquité. 110, 1, 1998, p. 297-350.

CASSIMATIS, Hélène. Le lébès à anses dressée italiote. Cahier du Centre Jean-Bérard, XV, Nápoles: Centre Jean-Bérard, École Française de Rome, 1992.

DELATTE, Armand. La catoptromancie grecque et ses dérivés. Bibliothèque de la Faculté de Philosophie et Lettres, 48. Liège: Université de Liège, 1932.

EDWARDS, Charles. Aphrodite on a ladder. Hesperia. 53, 1, 1984, p. 59-72, pr. 17-19.

FRONTISI-DUCROUX, Françoise; VERNANT, Jean-Pierre. Dans l'œil du miroir. Paris : Éditions Odile Jacob, 1997.

GLYN-JONES, Ann. Holding up a mirror. How Civilizations decline. Bowling Green, USA \& Thorventon, UK: Imprint Academic, 1996.

HARTLAUB, Georg Friedrich. Zauber des Spiegels. Geschichte und Bedeutung des Spiegels in der Kunst. München: Piper Verlag, 1951.

KNIGGE, Ursula. „O àot̀̀ Archäologischen Instituts, Athenische Abteilung. 97, 1982, p. 153-170.

KREILINGER, Ulla. Anständige Nacktheit. Körperpflege, Reinigungsritten und das Phänomen weiblicher Nackheit im archaisch-klassischen Athen. Tübinger Archäologische Forschungen, Band 2, Rahden/Westf.: Verlag Leidorf, 2007. 
KUNZE-GÖTTE, Erika. Frauengemachbilder in der Vasenmalerei des fünften Jahrhunderts. Dissertation, Klassische Archäologie, Universität München, München, 1957.

KUZMINA, Eugenia. El espejo: un misterio desde cuatro contiguidades. Escrita e imagen. vol. 9, 2012, p. 155-189.

LIND, Herrmann. Ein Hetärenhaus am Heiligen Tor? Der Athener Bau Z und die bei Isaios (6, 20f.) erwähnte Synoikia Euktemons. Museum Helveticum. Revue suisse pour l'étude de l'antiquité classique. 45, 3, 1988, p. 158-179.

MAFFRE, Jean.-Jacques. La vie dans la Grèce classique. Paris : PUF, 1988.

MELCHIOR-BONNET, Sabine. The Mirror: a History. New York, London: Routledge, 2002 (1994).

NILSSON, Martin P. Griechische Feste: von religiöser Bedeutung mit Ausschluss der Attischen. Stuttgart und Leipzig: B.G. Teubner, 1995 (1906).

RIDDER, A. de. s.v. "Speculum ", Dictionnaire des Antiquités grecques et romaines. Tome quatrième, deuxième partie. Paris: Hachette, 1909, p. 1422-1430.

MATTUSCH, Carol C. s.v. "Metalwork", The Oxford Encyclopedia of Ancient Greece \& Rome (ed. by Michail Gagarin and Elaine Fantham). Vol. I, Oxford: University Press, 2010, p. 399-404.

ROSENZWEIG, Rachel. Worshipping Aphrodite: Art and Cult in Classical Athens. Dissertation (2003). Ann Arbour: University of Michigan Press, 2004.

SARIAN, Haiganuch. Arqueologia da Imagem: aspectos teóricos e metodológicos na iconografia de Héstia. Rev. do Museu de Arqueologia e Etnologia, São Paulo, Suplemento 3, p. 69-84, 1999.

SCHNEIDER-HERRMANN, G. Apulian red-figured paterae with flat or knobbed handles. Bulletin Supllement n. 34, London: University of London, Institute of Classical Studies, 1977.

SCHNEIDER-HERRMANN, G. Spuren eines Eroskultes in der italischen Vasenmalerei. BABesch. 45, 1970, p. 86-117.

STARR, Chester G. An evening with the flute-girls. La Parola del Passato. 1978, p. 401-10. 
TREISTER, Michail Yu. The role of metals in Ancient Greek History. New York, Leiden, Köln: Brill, 1996.

VERGARA CERQUEIRA, Fábio. Espelho: imagens e significados na pintura dos vasos ápulos. In: Gil, R.; Alba, E.; Albaladejo, M.; Domènech, S. La visión especular: el espejo como tema y como símbolo. Barcelona: Editorial Calambur, 2018 (prelo).

VERGARA CERQUEIRA, Fábio. Os instrumentos musicais na vida diária da Atenas tardo-arcaica e clássica. O testemunho dos textos antigos e da iconografia dos vasos áticos. 3 volumes. Tese de doutorado. Antropologia Social. Faculdade de Filosofia, Letras e Ciências Humanas, Universidade de São Paulo, 2001.

VERNANT, Jean-Pierre. Au miroir de Méduse. In: Vernant, J.-P. L'individu, la mort, l'amour. Soi-même et l'autre en Grèce ancienne. Paris: Gallimard, 1989, p. 117-129.

ZÜCHNER, Wolfgang. Griechische Klappspiegel. Berlin: Walter de Gruyter, 1942. 